\title{
Tectonics
}

\author{
RESEARCH ARTICLE \\ 10.1029/2018TC005189 \\ Key Points: \\ - Dextral strike-slip wrenching \\ combined with orogen-normal \\ shortening, orogen-parallel \\ stretching, and local top-to-the-NE \\ shearing accommodate \\ synconvergence Leon dome \\ formation during the Variscan \\ orogeny \\ - A major sinistral Variscan shear \\ zone accommodate the tightening of \\ an orogenic syntax after the dome \\ formation
}

Correspondence to:

C. Authemayou,

christine.authemayou@univ-brest.fr

Citation:

Authemayou, C., Le Gall, B., Caroff, M., \& Bussien Grosjean, D. (2019).

Wrench-related dome formation and subsequent orogenic syntax bending in a hot orogen (Variscan

Ibero-Armorican Arc, the Ouessant Island, France). Tectonics, 38, 3563-3585. https://doi.org/10.1029/2018TC005189

Received 18 JUN 2018 Accepted 31 AUG 2019 Accepted article online 5 SEP 2019 Published online 11 OCT 2019

(c)2019. American Geophysical Union. All Rights Reserved.

\section{Wrench-Related Dome Formation and Subsequent Orogenic Syntax Bending in a Hot Orogen (Variscan Ibero-Armorican Arc, the Ouessant Island, France)}

\author{
Christine Authemayou ${ }^{1}$ D , Bernard Le Gall ${ }^{1}$ D, Martial Caroff ${ }^{1}$, and Denise Bussien Grosjean ${ }^{2}$ \\ ${ }^{1}$ Université Brest, CNRS, UMR6538 Géosciences Océan, Plouzané, France, ${ }^{2}$ Musée cantonal de Géologie, Quartier \\ UNIL-Dorigny, Bâtiment Anthropole, Lausanne, Switzerland
}

\begin{abstract}
During the Carboniferous collision stage, the West European Variscan orogen was affected by oblique convergence, wrenching, plate-scale oroclinal bending, and widespread exhumation of the deep crust. One of these exhumed units forms the Léon dome located on the northern flank of the Ibero-Armorican Arc in the western part of the Armorican massif. Structural field data from the Ouessant Island reveal kinematic changes between 330 and 300 Ma that affected the northwestern margin of the Léon dome. This margin underwent two ductile deformation phases with opposite strike-slip shear senses. Dextral strike-slip wrenching combined with orogen-normal shortening, orogen-parallel stretching, and local top-to-the-NE shearing occurred during the Léon dome formation and exhumation of its gneissic core at 330-310 Ma. During tightening of the Ibero-Armorican Arc at 300 Ma, more localized sinistral wrenching reactivated the northwestern boundary of the Léon dome. The resulting $\mathrm{N} 70^{\circ} \mathrm{E}$ trending sinistral Porspoder-Ouessant shear zone together with its conjugate dextral South Armorican shear zone controlled the lateral escape of the Léon-North-Central Armorican rigid tectonic wedge triggered by indentation of the Cantabrian orocline at the core of the Ibero-Armorican Arc.
\end{abstract}

\section{Introduction}

Wrenching is commonly observed in past and modern orogenic systems, oblique or parallel to the main direction of the orogen. Orogen-parallel transcurrent tectonics generally accommodates the lateral component of oblique convergence (Harland, 1971; Philippon \& Corti, 2016; Solar \& Brown, 2001) in a context of slip partitioning (Sanderson \& Marchini, 1984; Tikoff \& Teyssier, 1994). It is also encountered when tectonic escape (extrusion) occurs if a free external boundary exists and allows lateral motion of shallow structural units and lateral flow of deep crust in response to collisional shortening (Beaumont et al., 2001; Bird, 1991; Ratschbacher et al., 1991; Royden et al., 2008; Şengör et al., 1985; Tapponnier et al., 1986; Vanderhaeghe \& Teyssier, 2001). Less frequently, wrenching activates in the outer arc of curved orogenic systems during oroclinal buckling in order to accommodate arc-parallel stretching (Burg \& Podladchikov, 2000; Martínez Catalán, 2011; Shaw et al., 2012; Weil et al., 2013). Locally, wrenching accommodates block rotation (bookshelf tectonics; e.g., Freund, 1974; McKenzie \& Jackson, 1986) or dome formation during (1) transpression (Pêcher \& Le Fort, 1999; Mahéo et al., 2004; Yin, 2004), (2) lateral extrusion (Ratschbacher et al., 1991), (3) plate-scale buckling (Jolivet et al., 1999; Schneider et al., 2001), or (4) pullapart system formation (Denèle et al., 2017; Genser \& Neubauer, 1989; Le Pourhiet et al., 2012; Murphy \& Copeland, 2005; Rey et al., 2017; Roger et al., 2015; Steck, 2008).

The West European Variscan belt exposes many large strike-slip shear zones, revealing wrenching that largely contributed to orogenic construction (e.g., Arthaud \& Matte, 1977; Gapais \& Le Corre, 1980). These shear zones are interpreted as the result of (1) the accommodation of the lateral component of oblique convergence between Gondwana and Laurasia plates (Braid et al., 2011; Martínez Catalán, 2011; Pastor-Galán et al., 2015; Shelley \& Bossière, 2000), (2) the accommodation of indentation of an irregular pre-Variscan Gondwanan margin (e.g., Braid et al., 2011; Brun \& Burg, 1982; Casas \& Murphy, 2018; Dias \& Ribeiro, 1995; Matte \& Ribeiro, 1975; Matte, 1986; Kroner \& Romer, 2013; Llana-Fúnez \& Marco, 2007; Murphy et al., 2016; Perroud \& Bonhommet, 1981; Quesada, 1991; Ribeiro et al., 1995, 2007), and/or (3) the accommodation of oroclinal buckling leading to the Cantabrian orocline/Ibero-Armorican Arc (Casas \& Murphy, 

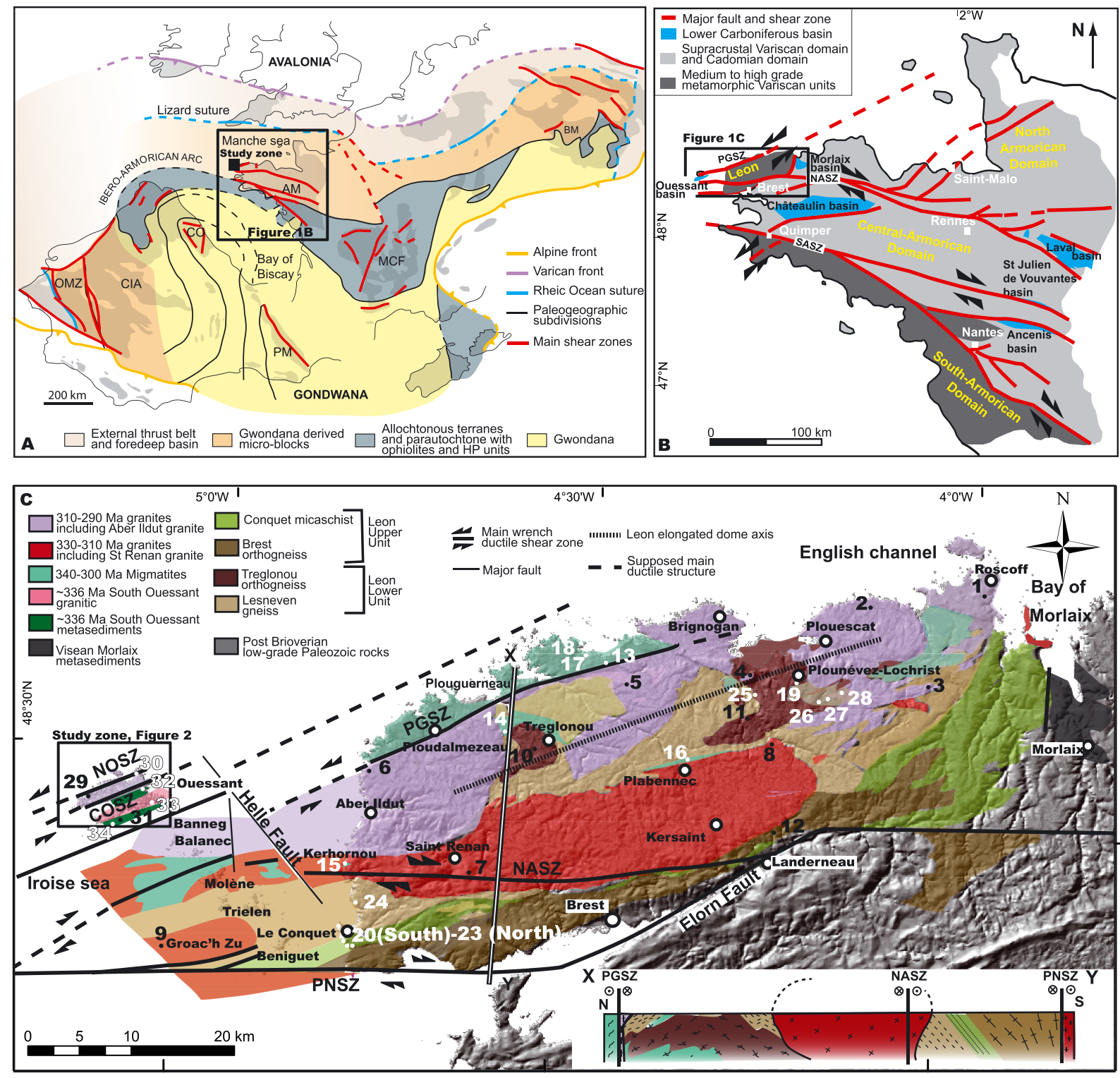

Figure 1. Tectonic context of the Ouessant Island. (a) Structural map and main tectonostratigraphic units of the European Variscan belt. The main outcrops of preMesozoic basement are presented in gray. Adapted from Martínez Catalán (2011) and Franke (2012). AM = Amorican Massif; MCF = Central Massif; PM = Pyrenean Massif; $\mathrm{CO}=$ Cantabrian orocline. (b) Location of the Ouessant Island within the shear zone patterns, structural units, and Tournaisian-Visean basins in the Armorican massif. (c) Geological features of the Léon dome and location of dated samples compiled in Table 1. Black and white numbers refer to magmatic and metamorphic samples, respectively.

2018; Cochelin et al., 2017; Edel et al., 2015; Gutiérrez-Alonso et al., 2012; Llana-Fúnez \& Marco, 2007; Martínez Catalán, 2011; Murphy et al., 2016; Pastor-Galán et al., 2015; Ribeiro et al., 2007; Shaw et al., 2015; Figure 1a). Many of these strike-slip shear zones bound gneiss domes and were active during exhumation of their cores with different tectonic scenarios proposed: transfer zones (Augier et al., 2015; Gapais et al., 2009), pull-apart bounding structures (Echtler \& Malavieille, 1990; Roger et al., 2015), or transpressional zone boundaries (Cochelin et al., 2017; Denèle et al., 2007, 2009; Rabin et al., 2015).

This paper focuses on the tectonic setting of the Ouessant Island that exposes the northwestern external boundary of the Léon dome, located in the western realm of the Variscan belt, in the outer IberoArmorican Arc (Faure et al., 2005, 2010; Jones, 1994; Le Gall et al., 2014; Schulz et al., 2007; Figures 1b and 1c). Dextral shearing active during dome exhumation has been reported on the southern part of the Léon dome (Le Gall et al., 2014), but no major contemporaneous detachment parallel to the main 
direction of the dome has been yet documented to drive its exhumation along the northwestern boundary, as it would be expected from both the northwestward dissymmetric shape of the dome and the asymmetry of regional metamorphic grades (Burg et al., 2004; Figure 1c). The only structural candidate in this area is the NE trending Porspoder-Guisseny sinistral shear zone, dated with the syntectonic Aber-Ildut porphyroid monzogranite at $\sim 300 \mathrm{Ma}$ (U-Pb zircon; Caroff et al., 2015). But this structure has been advocated to postdate dome exhumation (Figures $1 \mathrm{~b}$ and $1 \mathrm{c}$ and Table 1), contemporaneously with tightening of the IberoArmorican Arc (e.g, Brun \& Burg, 1982; Matte \& Ribeiro, 1975; Perroud \& Bonhommet, 1981; Figure 1a). The analysis of ductile strain in the Ouessant units, combined to published magmatic and metamorphic data, allows us to reassess the structural record of the Porspoder-Guisseny shear zone and to document its role during the Léon dome exhumation and subsequent tightening of the Ibero-Armorican arc. Resolving these issues, this case study allows to discuss the role of wrenching during two processes very frequently encountered in large orogens, that is, dome exhumation and orogenic syntax formation.

\section{Geodynamic Setting}

\subsection{The Armorican Massif Within the Variscan Belt}

The European Variscan orogenic belt is a fossil collisional zone with a current length of $\sim 3,000 \mathrm{~km}$ (Matte, 2001). It results from the Early Carboniferous (360-340 Ma) closure of marine basins, at least partly floored by oceanic crust, and the subsequent collision of large continental plates (Avalonia and Gondwana) and Gondwana-derived ribbon-like microcontinents (Ballèvre et al., 2009; Franke et al., 2017; Matte, 1986; Stampfli et al., 2013; Tait, 1999; Figure 1). In Western France, the Armorican massif is composed of a detached Gwondwana terrane, named Amorica (Figure 1a; e.g., Servais \& Sintubin, 2009; Stampfli et al., 2013 and references therein).

The Armorican massif (Figures $1 \mathrm{a}$ and $1 \mathrm{~b}$ ) is separated from the Lizard suture zone in Cornwall (England) to the north and from the Iberian units to the SW by the English Channel (La Manche) and the Bay of Biscay, respectively, that formed during Mesozoic rifting (e.g., Ziegler, 1987, 1994). However, some lithological connections can be made. According to detrital zircon signature, Paleozoic sedimentary series below the Lizard ophiolite show an Armorican origin in the context of a south verging subduction zone (Le Gall, 1990; Strachan et al., 2014). On the other hand, close palaeogeographical links and a similar Cadomian orogenic signature correlate Armorican domains with some Iberian units (Ballèvre et al., 2009; Franke, 2014; Franke et al., 2017; Ribeiro et al., 2009; Young, 1990; Figure 1a). All these zones constitute the IberoArmorican Arc orogenic structure (Figure 1a; Brun \& Burg, 1982; Burg et al., 1987; Dias \& Ribeiro, 1995; Matte \& Ribeiro, 1975; Perroud \& Bonhommet, 1981). In the core of the arc, the Cantabrian orocline is interpreted as a secondary structure formed by buckling during the late phase of the orogen between 310 and 295 Ma (e.g., Pastor-Galán et al., 2015; Weil et al., 2001, 2013). In this arc, activation of major transcurrent fault systems, associated with lateral mass transfer, allowed amplification of the orogenic structure (Arthaud \& Matte, 1977; Burg et al., 1994; Gapais et al., 2015; Gutiérrez-Alonso et al., 2012; Matte \& Ribeiro, 1975; Martínez Catalán, 2011; Figures 1a and 1b).

\subsection{The Léon Dome}

Our study area, the Ouessant Island, is located in the northwestern external part of the Léon dome at the northwestern end of the Armorican massif (Figure 1b). This dome forms an ENE-WSW trending doubly plunging antiform divided by a number of transcurrent ductile shear zones (e.g., Le Gall et al., 2014; Figure 1c). The dome shows roughly concentric foliation map patterns in its gneissic-migmatitic core (Paquette et al., 1987). The dome is cored by low-grade (Upper unit) to high-grade (Lower unit) metamorphic rocks intruded by 335- to 270-Ma granitoids and surrounded to the south and east by low-to-moderate grade Paleozoic sedimentary series of the Central Armorican domain (Faure et al., 2010; Le Corre et al., 1989; Marcoux et al., 2009; Rolet et al., 1986, 1994; Figures 1b and 1c and Table 1). The two metamorphic units are not separated by any major tectonic contact or metamorphic discontinuity (Le Gall et al., 2014; Schulz et al., 2007). The metamorphic grade of the Léon units increases northwestward, that is, downsection, from greenschist facies to partial melting conditions (Schulz et al., 2007; Schulz, 2013; Table 1). Relics of an eclogitic event are found locally in mafic lenses in the Lower unit (Cabanis \& Godard, 1987; Paquette et al., 1987). 
Table 1

Geochronological References for the Léon Dome and Ouessant Island

\begin{tabular}{|c|c|c|c|}
\hline Sites & Age (Ma) & Method & References \\
\hline \multicolumn{4}{|l|}{ Léon magmatic units } \\
\hline \multirow{2}{*}{ 1. Roscoff granite } & $275 \pm 5$ & Rb-Sr (biotite) & Leutwein et al. (1969) \\
\hline & $300 \pm 10$ & Rb-Sr (biotite) & Leutwein et al. (1969) \\
\hline 2. Brignogan/Plouescat cordierite granite & $292 \pm 15$ & $\mathrm{Rb}-\mathrm{Sr}$ (bulk rock) & Georget et al. (1986) \\
\hline 3. Ste Catherine leucogranite & $301.4 \pm 0.2$ & Ar-Ar (LA muscovite) & Marcoux et al. (2009) \\
\hline 4. Monzodiorite of Plounévez-Lochrist & $296 \pm 3$ & U-Pb (zircon, TIMS) & Marcoux et al. (2009) \\
\hline \multirow{2}{*}{$\begin{array}{l}\text { 5-6. Aber-Ildut porphyroid monzogranite } \\
\text { (and associated leucogranites, } \\
\text { migmatites, and lamprophyres) }\end{array}$} & (6) $301.4 \pm 4.3$ & U-Pb (zircon, TIMS) & Marcoux et al. (2009) \\
\hline & (7) $303.8 \pm 0.9$ & U-Pb (zircon, LA-ICPMS) & Caroff et al. (2015) \\
\hline \multirow[t]{3}{*}{ 7. Saint-Renan leucogranite } & $321 \pm 5$ & $\mathrm{U}-\mathrm{Th} / \mathrm{Pb}$ (in situ monazite, EPMA) & Faure et al. (2010) \\
\hline & $316.0 \pm 2.0$ & U-Th/Pb (in situ zircon, LA-ICPMS) & Le Gall et al. (2014) \\
\hline & $316.7 \pm 1.5$ & U-Th/Pb (in situ monazite LA-ICPMS) & Le Gall et al. (2014) \\
\hline \multirow[t]{2}{*}{ 8. Kersaint Leucogranite } & $331 \pm 4$ & $\mathrm{U}-\mathrm{Th} / \mathrm{Pb}$ (in situ monazite, EPMA) & Marcoux et al. (2009) \\
\hline & $328 \pm 7$ & $\mathrm{U}-\mathrm{Pb}$ (zircon, LA-MC-ICPMS) & Marcoux et al. (2009) \\
\hline 9. Groac'h $\mathrm{Zu}$ intrusive complex & $317.9 \pm 2$ & $\mathrm{U}-\mathrm{Th} / \mathrm{Pb}$ (in situ zircon, LA-ICPMS) & Le Gall et al. (2014) \\
\hline 10.Tréglonou orthogneiss & $385 \pm 8$ & $\mathrm{Rb}-\mathrm{Sr}$ (bulk rock) & Cabanis and Godard (1987) \\
\hline 11. Plounévez-Lochrist orthogneiss & $390.8 \pm 7.1$ & U-Pb (zircon, évap TIMS) & Marcoux et al. (2009) \\
\hline 12. Brest orthogneiss & $504 \pm 15$ & $\mathrm{U}-\mathrm{Th} / \mathrm{Pb}$ (in situ zircon, LA-MC-ICPMS) & Marcoux et al. (2009) \\
\hline \multicolumn{4}{|l|}{ Léon metamorphic units } \\
\hline 13. PGSZ mylonites & $292.6 \pm 2.7$ & Ar-Ar (LA muscovite) & Marcoux et al. (2009) \\
\hline 14. Treglonou migmatites & $334 \pm 6$ & $\mathrm{U}-\mathrm{Th} / \mathrm{Pb}$ (in situ monazite, EPMA) & Faure et al. (2010) \\
\hline $\begin{array}{l}\text { 15. Kerhornou migmatites (associated to } \\
\text { Saint-Renan leucogranite) }\end{array}$ & $325 \pm 5$ & $\mathrm{U}-\mathrm{Th} / \mathrm{Pb}$ (in situ monazite, EPMA) & Faure et al. (2010) \\
\hline $\begin{array}{l}\text { 16. Plabennec migmatites (associated to } \\
\text { Saint-Renan leucogranite) }\end{array}$ & $331 \pm 6$ & $\mathrm{U}-\mathrm{Th} / \mathrm{Pb}$ (in situ monazite, EPMA) & Faure et al. (2010) \\
\hline \multirow[t]{2}{*}{ 17. Plouguerneau migmatites } & $330 \pm 9$ & $\mathrm{U}-\mathrm{Th} / \mathrm{Pb}$ (in situ monazite, EPMA) & Marcoux et al. (2009) \\
\hline & $332 \pm 5$ & $\mathrm{U}-\mathrm{Th} / \mathrm{Pb}$ (in situ monazite, EPMA) & Marcoux et al. (2009) \\
\hline 18. Plouguerneau migmatites & $311 \pm 14$ & $\mathrm{U}-\mathrm{Th} / \mathrm{Pb}$ (in situ monazite, EPMA) & Schulz (2013) \\
\hline 19. Eclogite Plounévez Lochrist & $439 \pm 12$ & $\mathrm{U}-\mathrm{Pb}$ (zircon) & Paquette et al. (1987) \\
\hline 20. Le Conquet micaschists & $338 \pm 5$ & $\mathrm{U}-\mathrm{Th} / \mathrm{Pb}$ (in situ monazite, EPMA) & Faure et al. (2010) \\
\hline \multirow[t]{2}{*}{ 21. Le Conquet micaschists } & $302 \pm 5$ & $\mathrm{U}-\mathrm{Th} / \mathrm{Pb}$ (in situ monazite, EPMA) & Schulz (2013) \\
\hline & $304 \pm 5$ & & \\
\hline \multirow[t]{6}{*}{ 22. Le Conquet micaschists } & $513 \pm 15$ & $\mathrm{U}-\mathrm{Th} / \mathrm{Pb}$ (in situ monazite, EPMA) & Schulz (2013) \\
\hline & $512 \pm 14$ & & \\
\hline & $340 \pm 58$ & & \\
\hline & $340 \pm 36$ & & \\
\hline & $312 \pm 35$ & & \\
\hline & $304 \pm 21$ & & \\
\hline \multirow[t]{2}{*}{ 23. Lesneven gneiss } & $514 \pm 16$ & $\mathrm{U}-\mathrm{Th} / \mathrm{Pb}$ (in situ monazite, EPMA) & Schulz (2013) \\
\hline & $324 \pm 37$ & & \\
\hline 24. Lesneven gneiss & $527 \pm 11$ & $\mathrm{U}-\mathrm{Th} / \mathrm{Pb}$ (in situ monazite, EPMA) & Schulz (2013) \\
\hline 25. Lesneven gneiss & $309 \pm 12$ & $\mathrm{U}-\mathrm{Th} / \mathrm{Pb}$ (in situ monazite, EPMA) & Schulz (2013) \\
\hline 26. Lesneven gneiss & $309 \pm 11$ & $\mathrm{U}-\mathrm{Th} / \mathrm{Pb}$ (in situ monazite, EPMA) & Schulz (2013) \\
\hline 27. Lesneven gneiss & $300 \pm 10$ & $\mathrm{U}-\mathrm{Th} / \mathrm{Pb}$ (in situ monazite, EPMA) & Schulz (2013) \\
\hline 28. Lesneven gneiss & $306 \pm 12$ & $\mathrm{U}-\mathrm{Th} / \mathrm{Pb}$ (in situ monazite, EPMA) & Schulz (2013) \\
\hline \multicolumn{4}{|l|}{ Northern Ouessant unit } \\
\hline $\begin{array}{l}\text { 29. Two-mica leucogranite } \\
\text { (and associated microsyenites) }\end{array}$ & $303 \pm 5$ & $\mathrm{Rb}-\mathrm{Sr}$ (biotite) & Leutwein et al. (1969) \\
\hline 30. Migmatite & $295 \pm 8$ & $\mathrm{U}-\mathrm{Th} / \mathrm{Pb}$ (in situ monazite, EPMA) & Schulz (2013) \\
\hline \multicolumn{4}{|l|}{ Central and southern Ouessant units } \\
\hline $\begin{array}{l}\text { 31. Porphyroid monzogranite (and associated } \\
\text { leucogranites, trondhjemites and amphibolites) }\end{array}$ & $336.3 \pm 2.3$ & U-Pb (zircon, LA-ICPMS) & Caroff et al. (2016) \\
\hline 32. Micaschists & $314 \pm 21$ & $\mathrm{U}-\mathrm{Th} / \mathrm{Pb}$ (in situ monazite, EPMA) & Schulz (2013) \\
\hline 33. Micaschists & $295 \pm 28$ & $\mathrm{U}-\mathrm{Th} / \mathrm{Pb}$ (in situ monazite, EPMA) & Schulz (2013) \\
\hline 34. Micaschists & $303 \pm 7$ & $\mathrm{U}-\mathrm{Th} / \mathrm{Pb}$ (in situ monazite, EPMA) & Schulz (2013) \\
\hline
\end{tabular}

Note. Samples and units location in Figure 1c. 


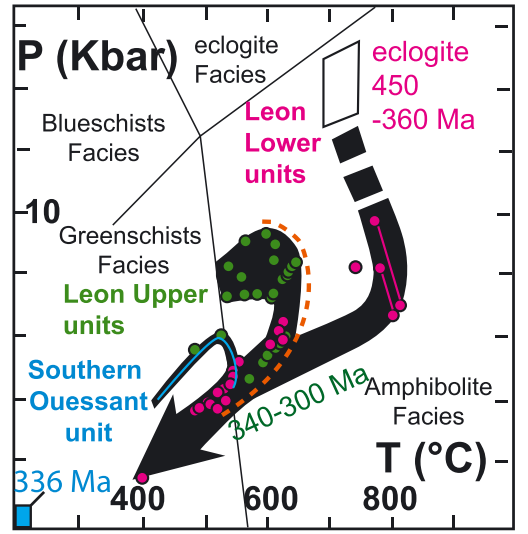

A

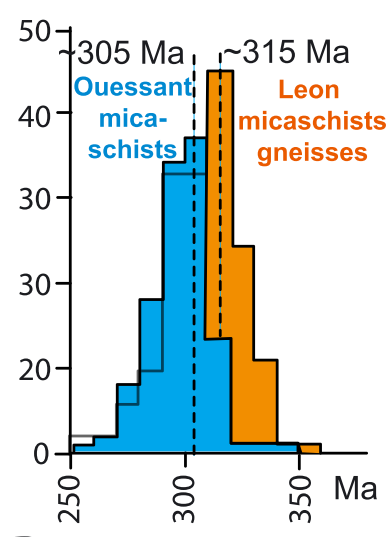

B

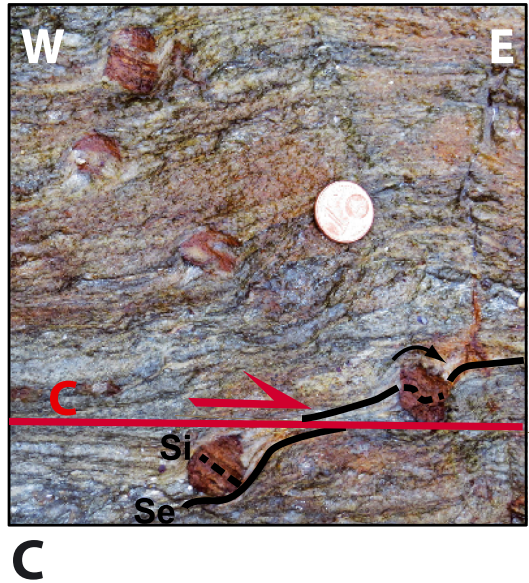

Figure 2. Tectono-metamorphic data of the Léon and Ouessant domains. (a) Carboniferous P-T data and P-T paths in the Upper Unit, Lower Unit of the Léon dome, and in the Ouessant Island according to Schulz et al. (2007) and Schulz (2013). P-T data from Ouessant were presented in a generalized way (Schulz, 2013). Orange line indicates part of paths with textural evidence for dextral-normal shearing (Jones, 1994). Blue square is the sedimentation event identified in the Southern Ouessant unit. (b) Frequency distribution of the CHIME-Th-U-Pb monazite Carboniferous ages from Léon micaschists/gneisses (green zone) and Ouessant micaschists (blue zone; Schulz, 2013). (c) Rotated garnets of the Léon upper unit with asymmetric pressure shadows associated with dextral-normal shearing (Le Gall et al., 2014). An internal schistosity ( $\mathrm{Si}$ ) is fossilized within the porphyroblasts, locally truncated by the external schistosity (Se) and clockwise rotated but still in the alignment of Se. Se is deflected by shearing (C plane).

The metamorphic evolution has been documented by combining mineral chemistry and P-T data from mineral assemblages (Cabanis \& Godard, 1987; Chantraine et al., 1986; Godard \& Mabit, 1998; Jones, 1993, 1994; Paquette et al., 1987; Schulz, 2013; Schulz et al., 2007). Results show that the Upper unit underwent a clockwise P-T path with a prograde metamorphism from $500{ }^{\circ} \mathrm{C} / 5 \mathrm{Kbar}$ to $600{ }^{\circ} \mathrm{C} / 8-9 \mathrm{Kbar}$ (Schulz et al., 2007; Figure 2a). Petrological data and the form of P-T paths indicate a period of heating during decompression process (Jones, 1994). The lower unit followed a different P-T path, starting at eclogite facies conditions (650-700 ${ }^{\circ} \mathrm{C}$ and at least $13-14 \mathrm{Kbar}$ ) and accompanied by heating during decompression within the granulite facies $\left(800^{\circ} \mathrm{C}\right.$ at $\left.8 \mathrm{Kbar}\right)$ and migmatization, with a final reequilibration in the amphibolite facies at low pressure $\left(600-500{ }^{\circ} \mathrm{C} / 5-4 \mathrm{Kbar}\right.$; Cabanis \& Godard, 1987; Chantraine et al., 1986; Godard \& Mabit, 1998; Paquette et al., 1987; Schulz et al., 2007; Figure 2a). Inverted metamorphic gradients or superposition of high-pressure units onto lower-pressure units, which provide arguments for nappe tectonics, is not documented in the Léon (Schulz et al., 2007). The weighted average ages of Carboniferous monazite populations, extracted from the orthogneiss of Plounevez-Lochrist, the Lesneven gneiss (Lower unit), and the Le Conquet micaschist (Upper Unit), range from $300 \pm 10 \mathrm{Ma}$ to $340 \pm 36 \mathrm{Ma}$ with a maximum at $\sim 315 \mathrm{Ma}$ in the Léon dome (Schulz, 2013; Figure 2b). In micaschists and gneisses, the monazites crystallize during a process involving a decompression/heating event followed by a decompression/cooling event occurring close to the Tmax of the clockwise P-T path of regional metamorphism. But it may be also possible that the monazites recorded thermal metamorphism in the vicinity of the Aber Ildut-Brignogan ( 300 Ma) and Saint Renan ( 316 Ma) granites during their emplacement (Caroff et al., 2015; Le Gall et al., 2014).

Prograde metamorphism is associated with top-to-the-NE transpressional sinistral ductile shearing (Balé \& Brun, 1986; Faure et al., 2010; Le Gall et al., 2014; Rolet et al., 1986). Rolet et al. $(1986,1994)$ proposed that this shearing underthrusts the Léon units relatively toward the southwest beneath the Central Armorican domain during the Variscan collision. Eclogitic rocks of Plounévez Lochrist located at core of the dome were dated by U/Pb on zircon (Paquette et al., 1987) and gave an age of $439 \pm 12 \mathrm{Ma}$ (Figure 1c and Table 1). This age could represent the high-pressure metamorphic event that follows the prograde metamorphism stage. But it is more probably a protolith crystallization age; the confusion stems from the lack of precision in the analytical methods during the 1980s (Paquette, pers. com.). Because the monazite ages of the Léon units provide no hint of any Silurian-Devonian thermal event, Schulz (2013) proposed an Early Carboniferous age of the Léon HP metamorphism. Age of the Léon dome exhumation was not directly constrained by any detailed geochrono-metamorphic study but was attributed to the Upper Carboniferous period ( 340-310 $\mathrm{Ma}$ ) by indirect arguments. Schulz et al. (2007) claimed that the younger Variscan monazite ages of Léon metamorphic units (340-300 Ma) indicate that these units were exhumed no earlier than the Upper 
Carboniferous. In the southern Léon dome boundary, microtextural evidence and metamorphic phase relations argue for the synchronicity between the dome exhumation, the thermal peak of P-T paths obtained during decompression and extensional shear zones with a dominant dextral strike-slip component (Jones, 1994; Figures 2a and 2c). Field-scale structural data and magmatic/tectonic analysis of high-resolution bathymetric map confirmed that this transtensional tectonic regime is partitioned into top-to-the SW shearing and localized dextral transcurrent shearing along the Pierres-Noires/Elorn and North Armorican shear zones contemporaneously with the emplacement of the Saint Renan granite and the Groac'h $\mathrm{Zu}$ intrusive complex, both robustly dated by $\mathrm{U}-\mathrm{Th} / \mathrm{Pb}$ on zircon and monazite at $316 \pm 2 \mathrm{Ma}$ and $318 \pm 2 \mathrm{Ma}$, respectively (Figure 1c and Table 1; Le Gall et al., 2014). Structural analysis of the North Armorican shear zone stated that dextral shearing occurred within pluton in a solid state during cooling (Goré and Le Corre, 1987). This magmatism was produced by significant melting of continental crust (Le Gall et al., 2014). Domains of migmatites dated from 340 to $297 \mathrm{Ma}$ by $\mathrm{U}-\mathrm{Th} / \mathrm{Pb}$ EPMA in situ monazite method, preserved in the northern part of the Léon dome, might also result from the same crustal melting process associated to dome exhumation (Faure et al., 2010; Goré \& Le Corre, 1987; Leutwein et al., 1969; Le Corre et al., 1989; Marcoux et al., 2009; Vanderhaeghe, 2009; Figure 1c and Table 1).

At around $300 \mathrm{Ma}$, regional-scale kinematics changed radically. The deformation focused on the sinistral N70 ${ }^{\circ}$ trending Porspoder-Guissény shear zone (PGSZ) located north of the Léon dome (Figure 1c). This shear zone is accompanied by synkinematic granitoids dated at around $300 \mathrm{Ma}$ by U-Pb zircon (Aber Ildut monzogranite; Caroff et al., 2015; Figure 1c and Table 1). Since granite intrusions in the Northern Ouessant Island and Aber Ildut areas postdate the Saint Renan granite and overlap the Léon metamorphic units, they thus postdate the Léon dome exhumation (Caroff et al., 2015). Eastward, in their alignment, a contemporaneous belt of orogenic granites was intruded over $300 \mathrm{~km}$, from Ouessant to the Cotentin Peninsula in Normandy (Chauris, 1991).

\subsection{The Ouessant Island Geology}

The Ouessant Island is the northernmost island of the Molene archipelago (Le Gall et al., 2014; Figure 1c). The ENE trending "crab claw" morphological pattern of the Ouessant Island, with central zone with low elevation pinched between two external promontories, reflects the geological arrangement of the island into several ENE trending major geological formations (Figure 3; Chauris \& Hallégouët, 1989). The Northern part of the island is mainly composed of the North Ouessant granitoid complex that comprises migmatitic gneisses and a $303 \pm 5$-Ma-old leucogranite dated by $\mathrm{Rb}$-Sr method on biotite and associated with granodiorite enclaves (northern unit; Caroff et al., 2015; Chauris \& Hallégouët, 1989; Table 1). The leucogranite is bounded to the south by an ENE trending brecciated syenogranite considered to belong to the same granitoid complex (Caroff et al., 2015). Evidence of sinistral ductile shearing is well expressed in the leucogranite. The granitoids intruded during sinistral ductile shearing (Caroff et al., 2015) and are overprinted by the emplacement of a network of NS trending quartz-microsyenite dikes that cut orthogonally through the sheared leucogranite (Figure 3; Caroff et al., 2015). The granitoids are correlated laterally toward the northeast with the Aber-Ildut intrusion along the PGSZ in the Léon dome (Caroff et al., 2015; Chauris \& Hallégouët, 1989; Le Gall et al., 2014; Figure 1c).

In the central part of the island, micaschists outcrop with some amphibolite bodies, intruded by a dense network of sodic dikes (trondhjemites; central unit; Figure 3). In the southern part of Ouessant, a complex of porphyroid monzogranites and leucogranites intruded the micaschist country rock (southern unit; Figure 3). The micaschists of the central and southern units were previously correlated with the undated upper Léon "Le Conquet-Penze micaschists" (Brioverian?) involved further south in the Léon dome (Chauris \& Hallégouët, 1989; Schulz, 2013). Recent field investigations focused on the relationship between the micaschist country rocks, and the intrusive monzogranite/leucogranite/trondhjemite complex have assessed this correlation (Caroff et al., 2016). In agreement with the definition of peperites as lobate or globular bodies of igneous rocks surrounded by metasediments (Brooks et al., 1982; Skilling et al., 2002; White et al., 2000), the fluidal peperites of pseudo-monzogranite identified in the South Ouessant unit indicate that magmatic bodies were emplaced in soft sedimentary deposits lying in a shallow basin (see Caroff et al., 2016 for details). The isotopic data obtained on the monzogranite are consistent with a continental crustal source for this magmatism: $(87 \mathrm{Sr} / 86 \mathrm{Sr}) \mathrm{i}=0.70631$ and $(\mathrm{epsNd}) \mathrm{i}=-2.8$ for an age of $336.3 \pm 2.3 \mathrm{Ma}$ obtained by U$\mathrm{Pb}$ dating on zircon (Caroff et al., 2016; DePaolo \& Wasserburg, 1976; Table 1). The metamorphic event 


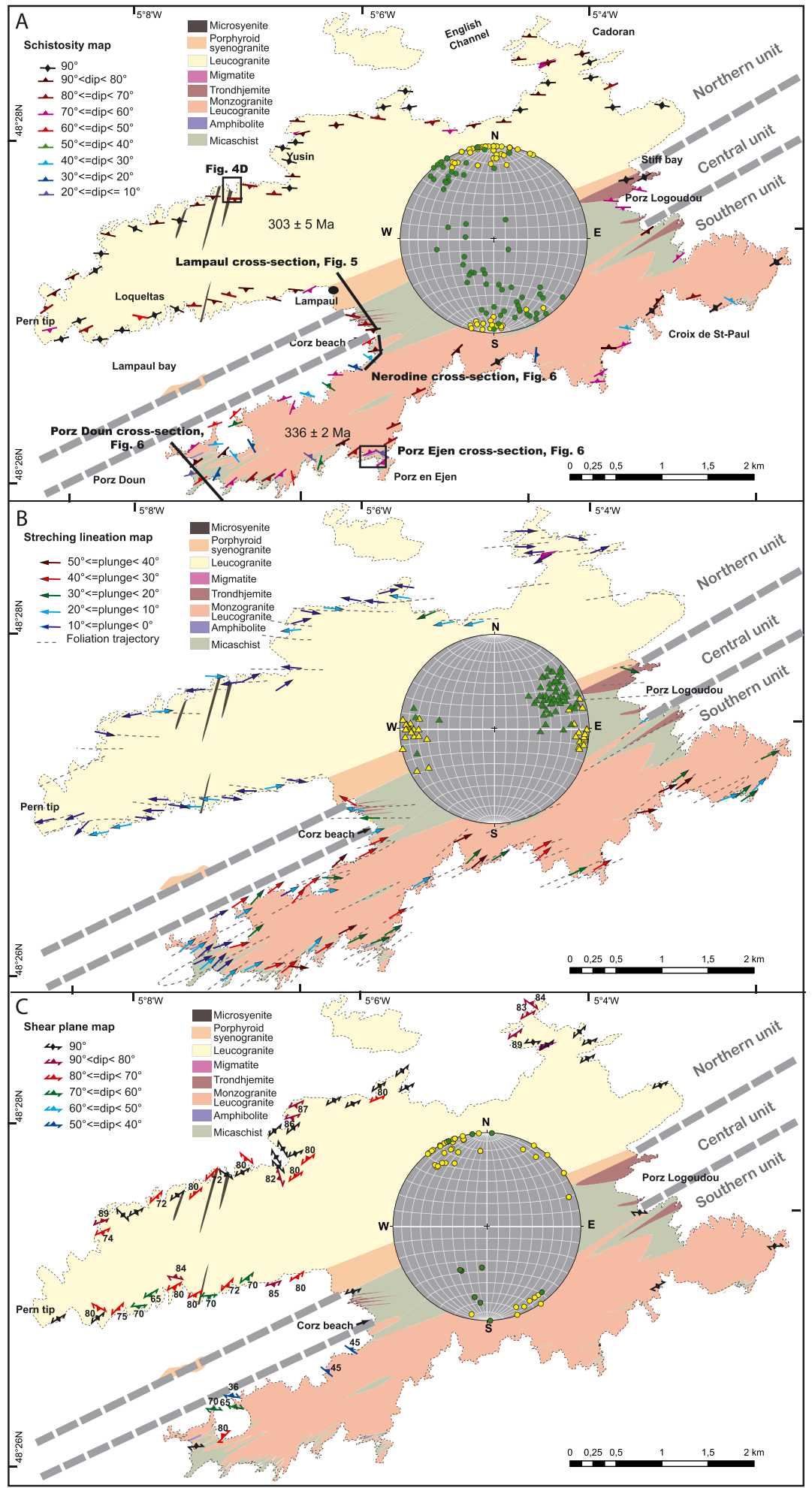

Figure 3. Structural analysis of ductile deformation in the Ouessant Island with lower hemisphere projection of structures superimposed on the geological map (Chauris, 1994). (a) Map of schistosity traces, (b) map of stretching lineation, and (c) map of shear planes. Ages of granitoid complex from Chauris (1994), Bioret et al. (2012), and Caroff et al. (2015, 2016). COSZ $=$ Central Ouessant shear zone; NOSZ $=$ North Ouessant shear zone. Locations of Figures 5d, 6, 7, 8, and 9 are shown. The yellow marks for each stereogram (circle for pole to schistosity, triangle for lineation, square for pole to shear plane) correspond to structures measured within the granitoid complex of the northern Ouessant unit. Green marks for each stereograms correspond to structures measured within the southern Ouessant unit. 
occurring after sedimentation only reaches the low amphibolitic facies (Schulz, 2013). It is too low to perturb the zircons. Thus, the age of $336.3 \pm 2.3 \mathrm{Ma}$ obtained with $\mathrm{U}-\mathrm{Th} / \mathrm{Pb}$ on zircon method of the synsedimentary intrusion dates the magmatic/sedimentary event and not the metamorphic event. This result indicates that the micaschists likely correspond to Visean sedimentary units deposited in a basin formed during the Variscan collision and prograde metamorphism of the Léon units (Caroff et al., 2016; Schulz, 2013; Figure 1c and Table 1). Visean sedimentary basins with a similar magmatic relation are known at the periphery of the Léon dome, for example, in the Central Armorican Domain (Chateaulin, Morlaix, Laval, Ancenis, and Saint-Julien-de-Vouvantes in Figure 1b; Darboux \& Le Gall, 1988; Gumiaux et al., 2004; Le Hérissé \& Plaine, 1982; Le Gall et al., 1992; Rolet et al., 1986). Various models have been proposed for the initiation and development of these Visean basins, either in a pull-apart context (Pelhate, 1994; Rolet, 1984) or in response to bending along transpressive faults (Gumiaux et al., 2004).

Following sedimentation, this southern unit was affected by ductile deformation and metamorphism. P-T paths from the Visean micaschists in the southern Ouessant domain indicate lower amphibolite facies, thus lower P-T conditions than in the Léon units, from $400{ }^{\circ} \mathrm{C} / 3.5 \mathrm{kbar}$ to $500{ }^{\circ} \mathrm{C} / 5 \mathrm{kbar}$ and then $600{ }^{\circ} \mathrm{C} / 4 \mathrm{kbar}$ with no evidence of several separate mineralogical assemblages (Schulz, 2013; Figure 2a). The thermal peak of P-T paths is obtained during decompression as in the Léon dome (Schulz, 2013). The weighted average monazite ages from these series range from $295 \pm 28$ Ma to $314 \pm 21$ Ma on the Ouessant Island with a peak at $305 \mathrm{Ma}$ (Schulz et al., 2007; Schulz, 2013; Figure 2b).

\section{Methods}

We performed a structural analysis of all lithotypes/units (micaschists, granites) of the Ouessant Island, identifying the ductile structures (schistosity, lineation, fold, and shear zone) to interpret them in terms of strain (strain ellipsoid and coaxial versus noncoaxial) and to discuss the results in terms of kinematic framework, driving forces and plate kinematics associated with the Leon gneiss dome formation and the orogenic evolution of the Variscan belt. To perform this structural analysis, we have measured and compiled the planolinear fabrics and associated kinematic criteria (S-C fabrics, sigmoid-shaped plagioclase, and fold asymmetry). The tectonic structures were projected on a Schmidt's lower hemisphere equal-area projection using Stereonet software. We collect rock samples containing porphyroclasts and ductile structures that were clearly visible to study the microstructural fabric. Most of the geological and structural investigations have been carried out along coastal sections that provide continuous exposure along the western and southwestern parts of the island. To address the chronology of highlighted deformations and their correlation with the tectonometamorphic and magmatic histories of the Léon units, we compiled the ages of magmatic units and metamorphic data of the two domains (Léon and Ouessant) from the bibliography (Figures 1c and 2 and Table 1). Recent geochronological analyses were considered the most relevant due to progress in measurement accuracy and machine detection level. Representative schistosity, stretching lineation, and shear plane field measurements are reported in Figure 3.

\section{Structural Analysis}

A drastic change in orientation of schistosity (Figure 3a) and stretching lineation (Figure 3b) occurs on either side of the central and southern units. To the north, the schistosity and stretching lineation are mainly E-W, whereas to the south, they are generally NE-SW. The orientation of shear planes and the sense of shear criteria also differ on either side of this boundary with uniform NE trending sinistral shearing to the north and heterogeneous senses and directions of shearing to the south (Figure 3c).

\subsection{The Northern Unit}

The northern unit is affected by a dominant pervasive schistosity (S1) defined by the preferred orientation of quartz, feldspar, biotite, and muscovite. This planar fabric is oriented dominantly $\mathrm{N} 90^{\circ} \mathrm{E}$, that is, oblique to the $\mathrm{N} 70^{\circ} \mathrm{E}$ trending lithological boundaries (Figures 3a and 4a), displays vertical-subvertical dips, and is not overprinted by any younger ductile deformation (Figures $3 \mathrm{a}$ and $4 \mathrm{~b}$ ). This schistosity plane generally carries a subhorizontal pervasive stretching lineation that plunges on average $3^{\circ}$ toward $\mathrm{N} 261^{\circ}$ (Figures $3 \mathrm{~b}$ and $4 \mathrm{~b}$ ). This lineation is defined by stretched quartz as well as feldspar or mica preferred orientation. 
NORTHERN UNIT
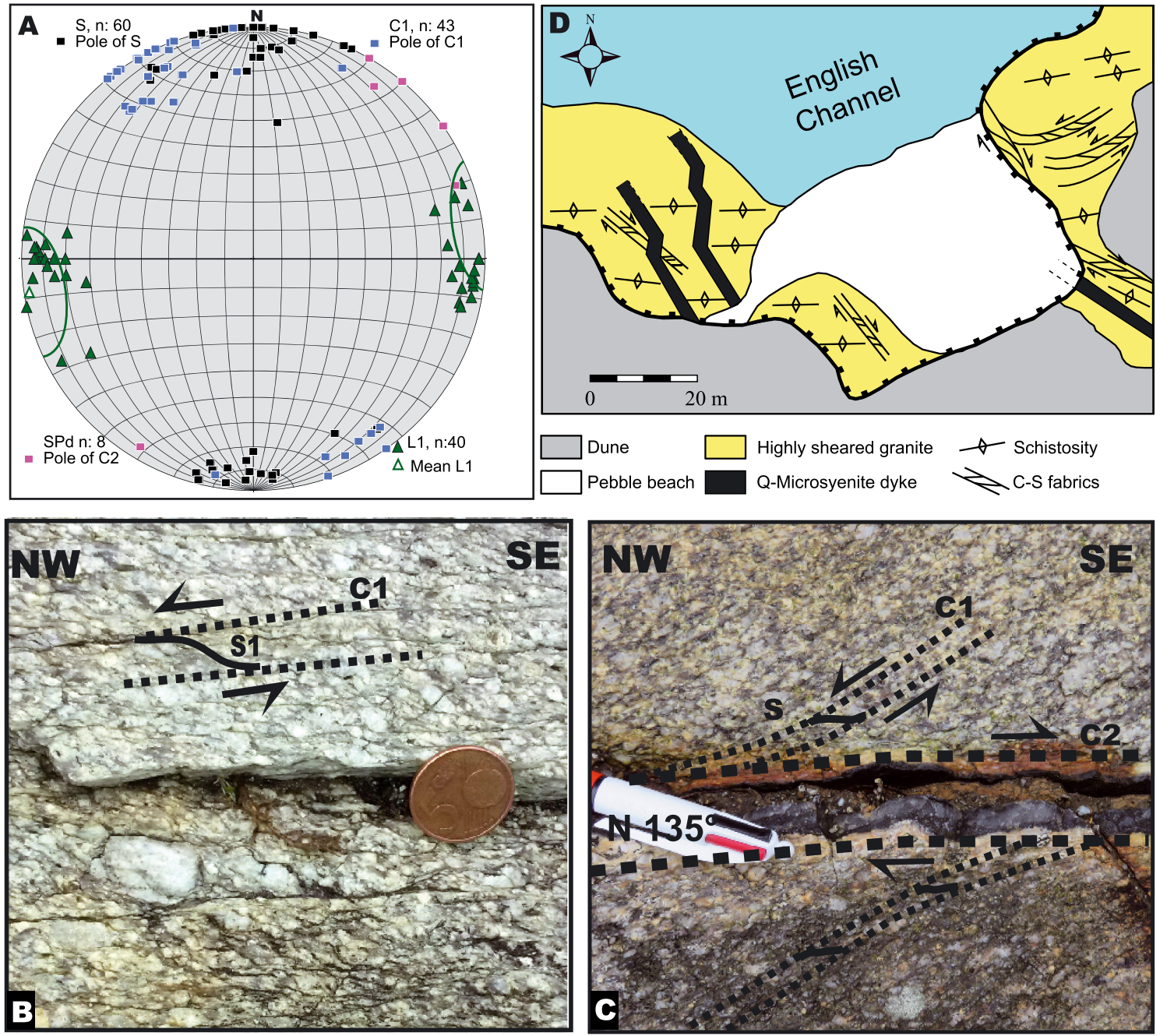

Figure 4. Structural analyses of the northern granitoid complex showing relationships between sinistral and dextral shearing and microsyenite dikes. (a) Schmidt's lower hemisphere equal-area projection of the structures using Stereonet software (b) Sinistral S-C fabrics (S, schistosity). (c) Decimeter-scale late dextral shear bands affecting sinistral S-C fabrics and associated with pegmatitic mineralization (C2, dextral shear plane; C1, sinistral shear plane). (d) Sketch structural map of the site. Location shown in Figure 2.

The E-W striking schistosity is closely associated with vertical shear planes (C1), striking dominantly $\mathrm{N} 70^{\circ} \mathrm{E}$ (Figures $3 \mathrm{c}$ and $4 \mathrm{~b}$ ) in pervasive S-C fabrics indicating sinistral shearing (Figure $4 \mathrm{c}$ ). S and $\mathrm{C}$ surfaces likely formed synchronously since they show no overprinting relation, such as schistosity boudinage, schistosity folding, or extensional crenulations (Lister \& Snoke, 1984). The S-C fabrics are encountered in two corridors of deformation located north and south of the Pern point, at the western end of the island (Figure 3c). This region consists of two sinistral $\mathrm{N}^{\circ} 0^{\circ}$ trending ductile shear zones, namely, the North and Central Ouessant Shear Zones (NOSZ and COSZ, respectively in the text; Figure 1c; Caroff et al., 2015). Sharp strain gradients are evidenced across $\sim 10-\mathrm{m}$-wide zones by decreasing S-C angle and C plane spacing. More locally, S-C fabrics in strained migmatites and associated magmatic mélanges in the northern Yusin and Cadoran areas are either folded by drag folds or disrupted by $\mathrm{C}^{\prime}$ sinistral shear planes (Figure 3c). Within the NOSZ, S-C sinistral fabrics are locally deflected by discrete dextral shear planes (C2), outlined by tourmaline/quartz-filled pegmatites and consistently oriented at $\mathrm{N} 140-150^{\circ} \mathrm{E}$ (Figures $4 \mathrm{a}$ and $4 \mathrm{~d}$ ). A quartz-microsyenite dike swarm postdates granitoid emplacement and crosscuts the dextral shear zones. 


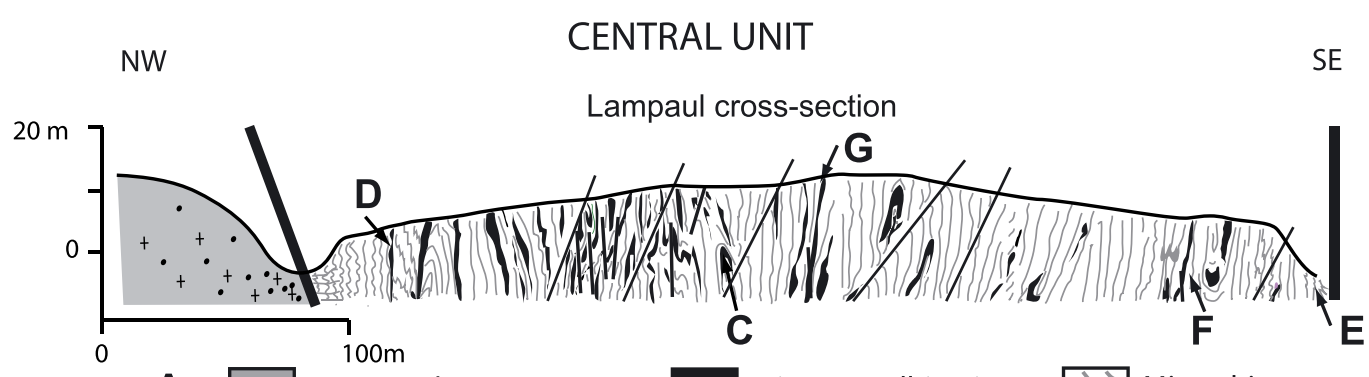

A $+: .+$ Brecciated syeno-granite $\square$ Micro-trondhjemite $\$$ Micaschist
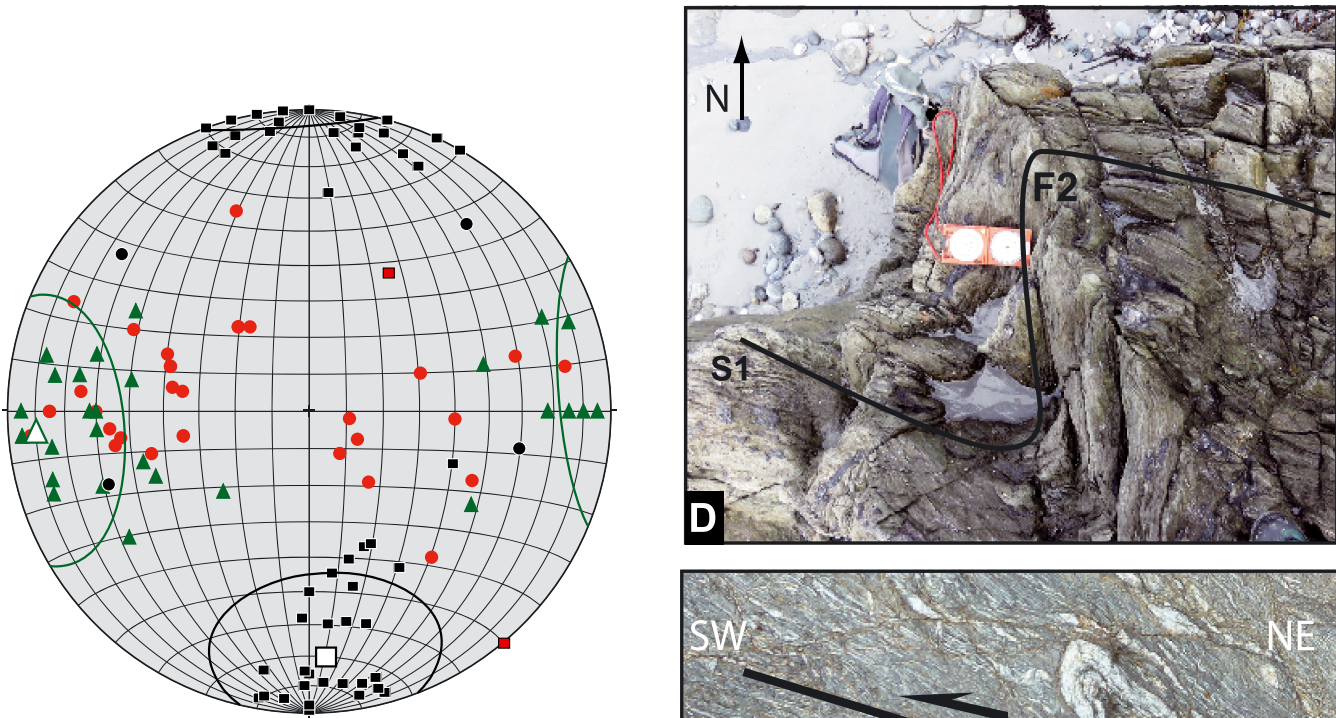

$\triangle \mathrm{L} 1$

- Fold axis F2

B $\square$ Mean pole of $\mathrm{S} 1 \triangle$ Mean L1 $-\mathrm{S} 2$ of crenulation - Fold axis F1
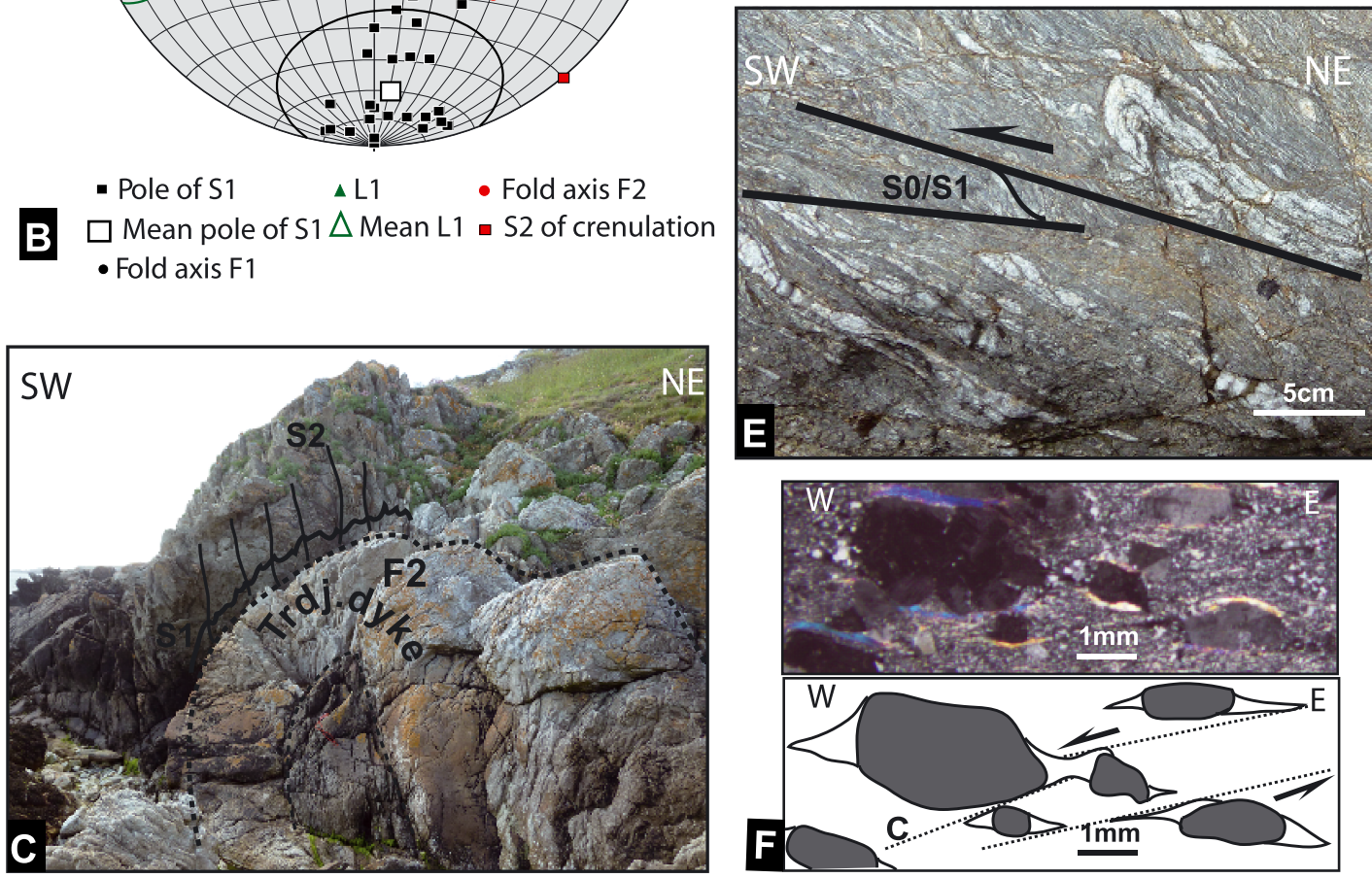

Figure 5. Structural analyses of the Lampaul cross section. (a) NW trending structural and geological cross section. (b) Schmidt's lower hemisphere equal-area projection of the structures using Stereonet software. (c) Folded trondhjemite (trdj) dike displaying two superimposed schistosity planes (pervasive shistosity S1 and the crenulation schistosity S2). (d) Asymmetric folding of S1 with steep axis. (e) Sinistral shear bands associated with drag folds involving S1. (f) Photomicrograph of trondhjemite dikes, section (parallel to the stretching lineation [L1] and perpendicular to subvertical S1) highlighting sigmoid-shaped porphyroclasts of plagioclases. Location shown in Figure 3.

\subsection{The Central Unit}

South of the northern granitoid complex, the micaschist series and the associated trondhjemite dikes are continuously exposed along a 300-m-long coastal section at Lampaul (Figures 3 and 5a). In contrast with 


\section{SOUTHERN UNIT}
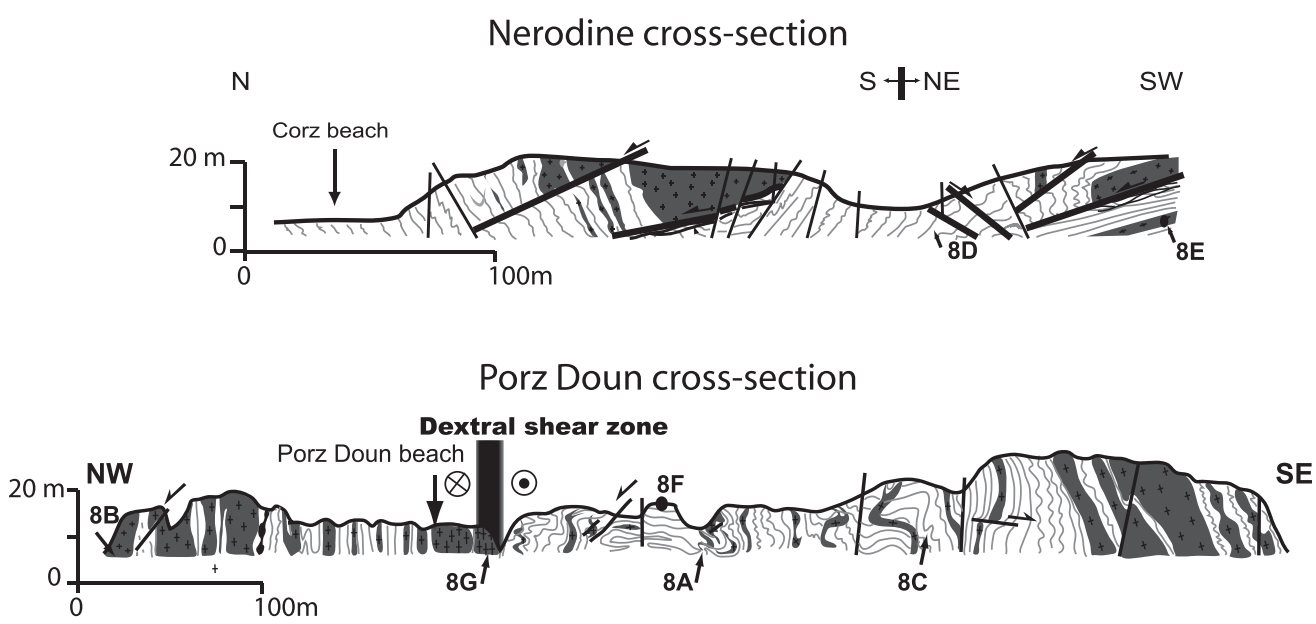

Porz en Ejen cross-section

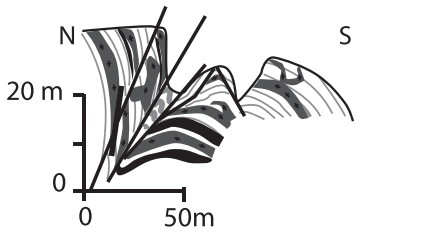

$\begin{array}{ll}\text { Amphibolite } & \\ \text { Fault } & \text { Brittle-ductile shear zone }\end{array}$

Figure 6. Geological cross sections of Nerodine, Porz Doun, and Porz en Ejen sites in the southern units.

the northern unit, the micaschist and trondhjemite units both show clear evidence of polyphase deformation. The micaschists are affected by a pervasive schistosity reworking the original stratification observed by various tones of gray in the micaschists, referred to as S1, that is generally orientated approximately $\mathrm{N}^{\circ} 0^{\circ} \mathrm{E}$ and steeply dipping (Figures $3 \mathrm{a}$ and $\mathrm{4b}$ ). The schistosity is defined by oriented micas and flattened quartz veins and is oblique to the $\mathrm{N} 70^{\circ} \mathrm{E}$ trending lithological boundaries but parallel to the swarm of transposed trondhjemite dikes. Generally, the EW striking S1 is parallel to very thin silt layers that outline the bedding (S0) and thin quartzite bands that bear a pronounced subhorizontal stretching lineation (plunges on average $10^{\circ}$ toward $\mathrm{N}^{2} 65^{\circ}$ ). This stretching lineation is also well expressed in the trondhjemite intrusives outcropping as $10 \mathrm{~cm}$ to $>2$-m-thick bodies, systematically parallel to the S0 surfaces, and thus considered as dike intrusions. The S1 planes are folded into EW trending folds (F2; Figures $5 \mathrm{~b}$ and $5 \mathrm{c}$ ) that are, in some places, associated with an EW striking crenulation schistosity (S2; Figure 5c). The relatively thick multimetric dikes are affected by open folds (F2), with subhorizontal axes, but more commonly, the micaschists planar fabric (S1) is involved in small-scale F2 folds with steeply plunging axes (Figure 5b). The asymmetry of F2 folds systematically indicates a sinistral sense of shear (Figure 5d). A similar sinistral sense of post-S1 shearing is evidenced on the northern boundary of the micaschist unit by subvertical shear bands that cause steeply plunging drag folds of S1 surfaces (Figure 5e). In trondhjemite dikes, thin sections, cut parallel to the stretching lineation (L1) and perpendicular to the subvertical S1, show sigmoid-shaped plagioclase in agreement with sinistral sense of shear on C planes (Figure 5F).

\subsection{The Southern Unit}

South of Corz beach, the structural style changes drastically, together with the lithological change expressed mainly by the replacement of trondhjemite dikes by a dike network of monzogranite, leucogranite, and amphibolite associated with micaschists in the host rocks (Figure 3). Three cross sections, referred to as 

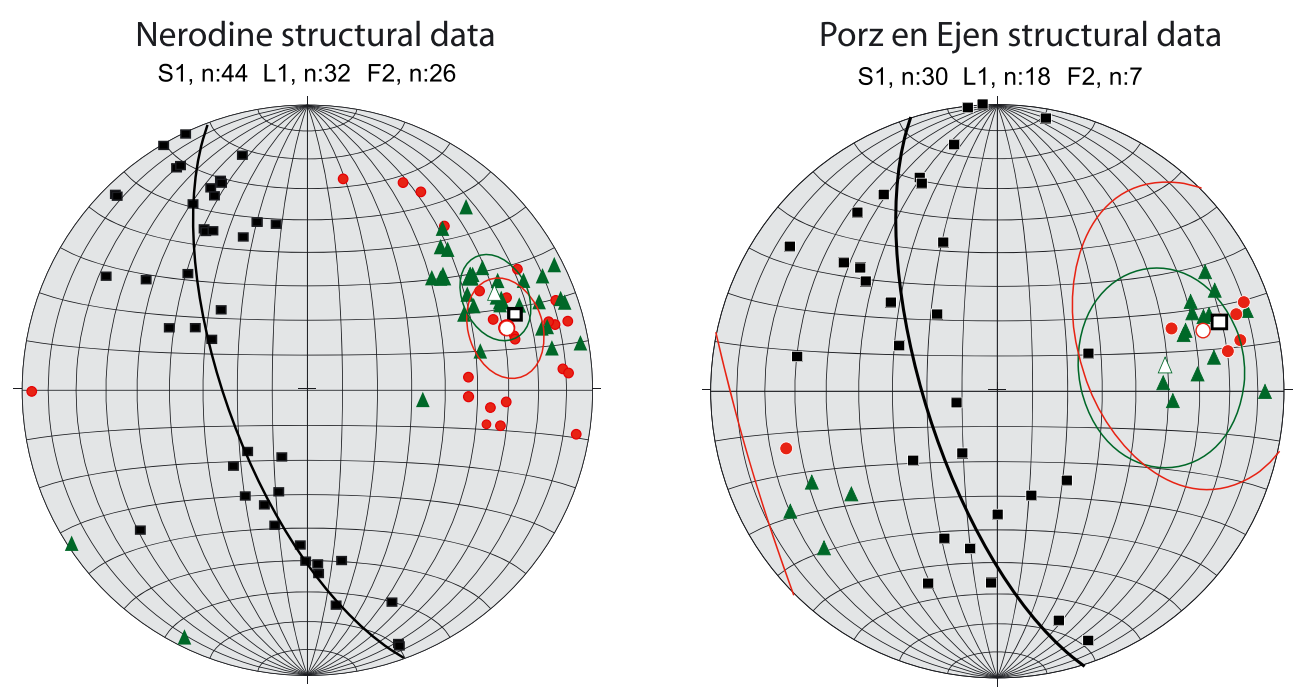

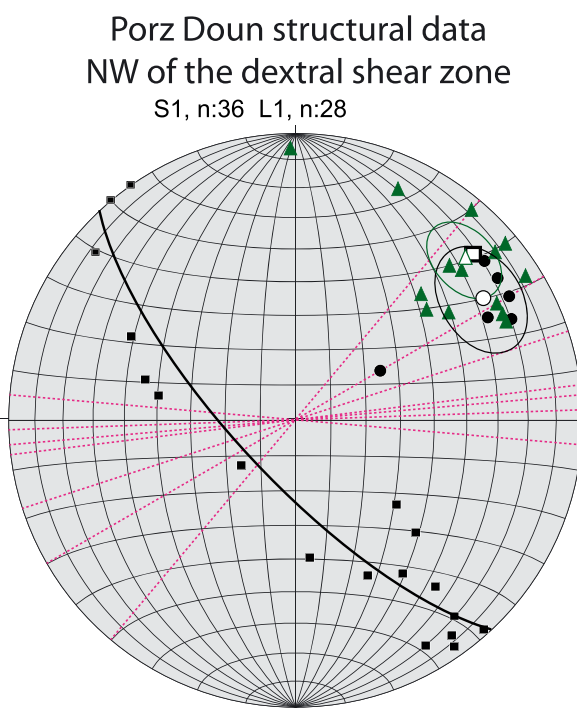

\section{Porz Doun structural data}

SE of the dextral shear zone $\mathrm{S} 1, \mathrm{n}: 32$ L1, n:25 F2, n:14

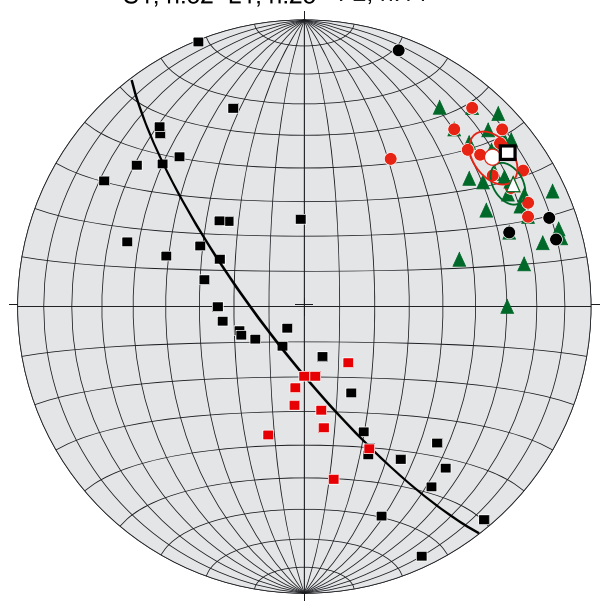

- Pole of S1

$\Delta \mathrm{L} 1$

- Fold axis F2

Mean F2 axis

- Fold axis F2
- Pole of S2

...dextral shear plan best fit S1

Figure 7. Schmidt's lower hemisphere equal-area projection of the structures in Nerodine, Porz Doun and Porz en Ejen sites using Stereonet software.

the Nerodine, Porz Doun, and Porz en Ejen sites, display evidence of heterogeneous deformation (Figure 6) but with fairly consistent trends of structures (Figure 7). The pervasive schistosity, referred to as S1 (the stratification S0 distinguished by various tones of gray in micaschists being folded with an axial plane parallel to the schistosity S1), strikes NE-SW on average (Figures 3a and 7). Some flattened quartz veins in micaschists or monzogranite dikes are folded with an axial plane parallel to the schistosity (F1 fold; Figure 8a). Globally, the dip of the schistosity is subvertical, but locally, the planes turn toward a NW trending strike, generally associated with a $40^{\circ} \mathrm{NE}$ to $20^{\circ} \mathrm{NE}$ dip (Figure 3a). Variations in dip occur gradually along large-scale flexures or more abruptly on either side of major faults (Figure 6). The S1 planes affecting both micaschists and intrusion bodies show a pervasive and consistently oriented stretching lineation (L1), plunging slightly $\left(20^{\circ}\right.$ on average) to the $\mathrm{NE}$ (N60 ${ }^{\circ}$ to $\mathrm{N} 40^{\circ}$; Figures $3 \mathrm{~b}$ and 7 ). Locally, in the northwesternmost part of the Porz section, a transition from S-L to L tectonites is documented by the occurrence of a dominant linear fabric outlined by porphyroclasts of plagioclase within monzogranite and stretched micaschist enclaves (Figure 8b). 

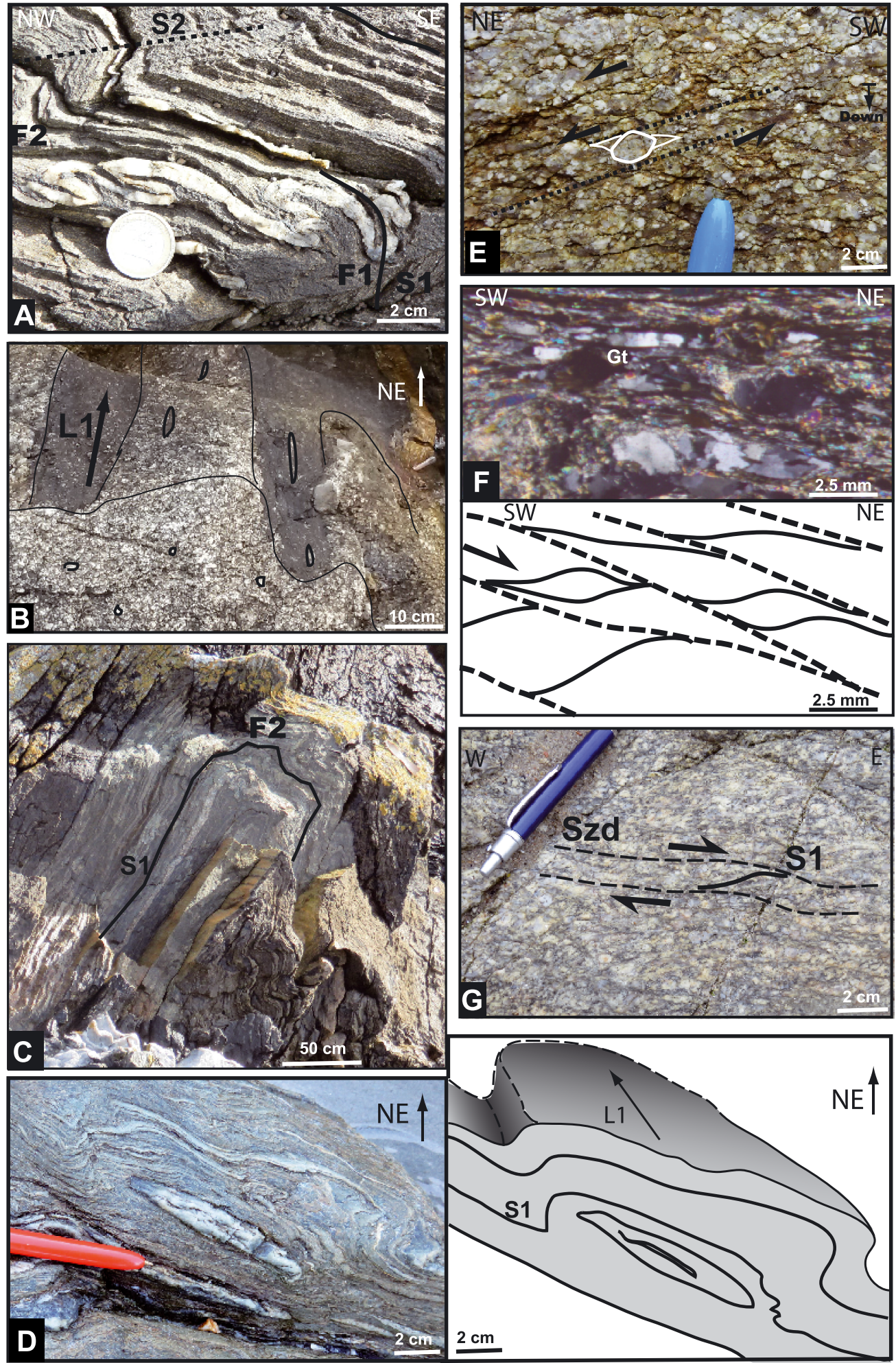

Figure 8. Pictures of outcrops and thin sections of the southern unit. (a) Multistage folding with F1 folds contemporaneous to the schistosity S1, involved into (F2) folds producing a crenulation schitosity S2. (b) Linear fabric with the stretching lineation (L1) within the mozogranite and stretched micaschist enclaves. (c) F2 isoclinal fold affecting the S1 schistosity in the micaschists. (d) Symmetrical-shaped sheath fold with axis parallel to the stretching lineation L1 and associated simplified sketch. (e) NW trending shear planes dipping toward the NE with sigmoïd-shaped feldspars. (f) Microphotograph of monzogranite dikes, thin section parallel to the stretching lineation (L1) and perpendicular to the nearly flat schistosity S1, with sigmoïd-shaped porphyroclasts of feldspars and garnet redrawn. Note the lack of internal schistosity within the garnets. (g) E-W dextral shear zones showing S-C fabrics. Location shown in Figure 6. 
The variable dip of S1 planes results from folding (F2) with axes plunging from NNE to ENE (Figure 7). F2 fold structures are well exposed at various scales along the Porz-Doun section (Figures 8a and 8c). They are generally open and less frequently isoclinal and are locally associated with a crenulation cleavage (S2), generally dipping shallowly to N-NE (Figure 8a). Veins are isoclinally folded, and their flanks are boudinaged (Figure 8a). In all cross sections, poles of S1 show a cylindrical best fit, the pole of which trends at 30-20 to the NE. This axis corresponds to the mean F2 axis (Figure 6). F2 axes also trend parallel to the stretching lineation (L1; Figure 7). Few dm-scale sheath-like folds F2 are observed, indicating a gradient in shear strain (Figure 8d).

The schistosity $\mathrm{S} 1$ is frequently associated with shear planes in typical S-C fabrics in monzogranite dikes. Where schistosity has a gentle NE dip, a top-to-the-NE sense of shear is indicated by the asymmetric shape of elongated sigmoidal feldspar porphyroclasts observed at outcrop scale (Figure 8e) or by the sigmoidal shape of micas observed in thin sections (Figure 8f). Locally, where schistosity is nearly vertical, a dextral sense of shear is documented by a pervasive vertical $\mathrm{S}-\mathrm{C}$ fabric (Figures 7 and $8 \mathrm{~g}$ ).

\section{Interpretation}

Our structural analysis of the Ouessant units reveals a variety of ductile fabrics and kinematic indicators (Figure 9). In the northern granitoid complex (northern unit), planar/linear (SL) fabrics are dominated by an EW striking subvertical schistosity (S) and a subhorizontal strike-parallel stretching lineation (Figure 9). The consistent S-C fabrics in the 1-km-wide NOSZ and COSZ corridors indicate sinistral shearing (Figure 9). The evidence for sinistral ductile strain further south in the central unit corresponds to asymmetric folding (F2) that overprinted S1 in the Visean micaschists/trondhjemite series. Thus, the effects of sinistral shearing are recorded as far south as the micaschist/trondhjemite series in the central unit. The strain regime associated with S1 in the micaschists could not be determined because it was totally transposed by the second deformation phase. The homogeneous spatial relationship of schistosity and lineation in the northern unit is interpreted to reflect a regime of orogen-parallel strike-slip flow as defined by Chardon et al. (2009; yellow squares; Figure 10). Flow obliquity in relation to the orogen direction increases in the micaschist/trondjhemite series in the central unit, possibly due to superimposed strain (green squares; Figure 10).

In the southern unit, the deformation changes drastically and affects only Visean metasediments and synchronous granitoid intrusions. The S1 has a NE strike compatible in first order with a NW-SE trending horizontal shortening axis $(Z)$. This shortening axis likely represents the orogen-perpendicular shortening direction according to the elongation of the Léon dome (Figure 1c; Le Gall et al., 2014). Three different fabrics are distinguished in the southern unit (Figure 9). Two of them are steeply or gently dipping planar/linear (SL) fabrics; the third is a linear (L) fabric. Locally, the (L) fabric does not overprint a previous fabric, indicating pure constrictional strain. The direction and plunge of this (L) fabric are similar to those measured in the steeply and gently dipping (SL) fabrics. All fabrics bear mineral lineations plunging to the NE at a low angle to the Léon orogenic system. In (SL) fabric units, where the main schistosity (S1) is steep, it is commonly overprinted by F2 folds. Given (1) the parallelism of F2 fold axis and L1 stretching lineation (Figure 7), (2) the presence of F2 sheath folds, and (3) the pole axis of the crenulation cleavage (S2) on the cylindrical best fit $\mathrm{S} 1$, the pole of which trending at $30-20^{\circ}$ to the NE similarly to L1 stretching lineation (Figure 7), we frame the whole ductile strain pattern in a single deformational process and not and in a superposition of successive discrete deformation events. The constrictional deformation, F2 folds, and crenulation cleavage (S2) indicate both transverse and vertical shortening. These fabrics are thus compatible assuming rotation around an axis parallel to the lineation with the permutation of $Y$ and $Z$ finite strain axes (Figure 9). The localized linear fabric could be produced by intense stretching from these planar-linear fabrics. Besides, a single mineral assemblage consistent with low-grade metamorphism has been recognized in the southern Ouessant units (Schulz, 2013). Consequently, it is suggested that deformation in the southern unit results from the interaction of three contemporaneous strain patterns without fabric overprinting. According to this kinematic scenario, the strain pattern changes either spatially by deformation partitioning (e.g., Fossen et al., 2018) or progressively through time from plane strain to constriction (fabric L > S). In the latter case, $\mathrm{S} 1$ that is progressively folded in response to intense stretching that induces shortening along both the $Y$ and $Z$ strain axes finally leads to the development of S2 (Figure 9). 


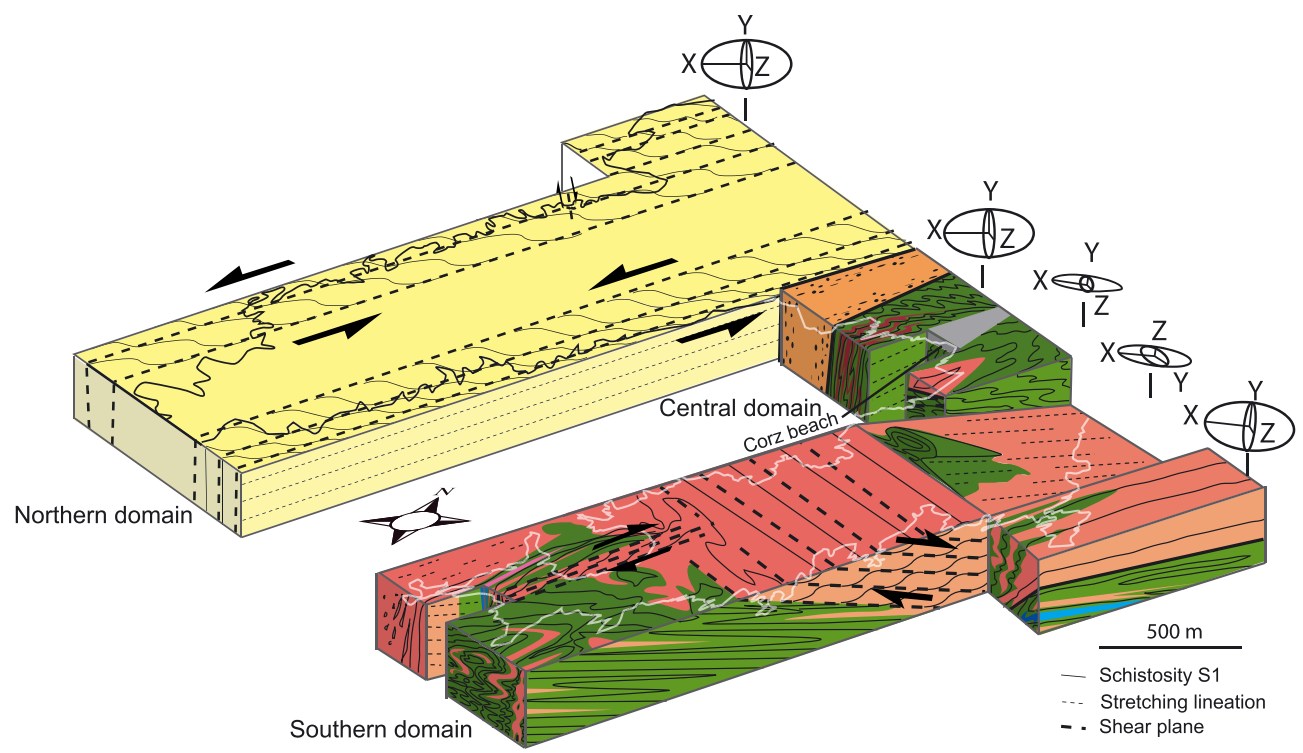

Figure 9. Kinematic framework of ductile deformation in the Ouessant Island. Sketch summarizes the relations between the ductile structures and strain ellipsoids. For geological units see Figure 3.

Localized NE trending dextral shear zones are spatially associated with steep (SL) fabric, and the top-to-theNE shear zones occur along the gently dipping (SL) fabric. As the two fabrics are arguably synchronous, given that their principal directions of stretching are almost parallel, this also suggests synchronicity between

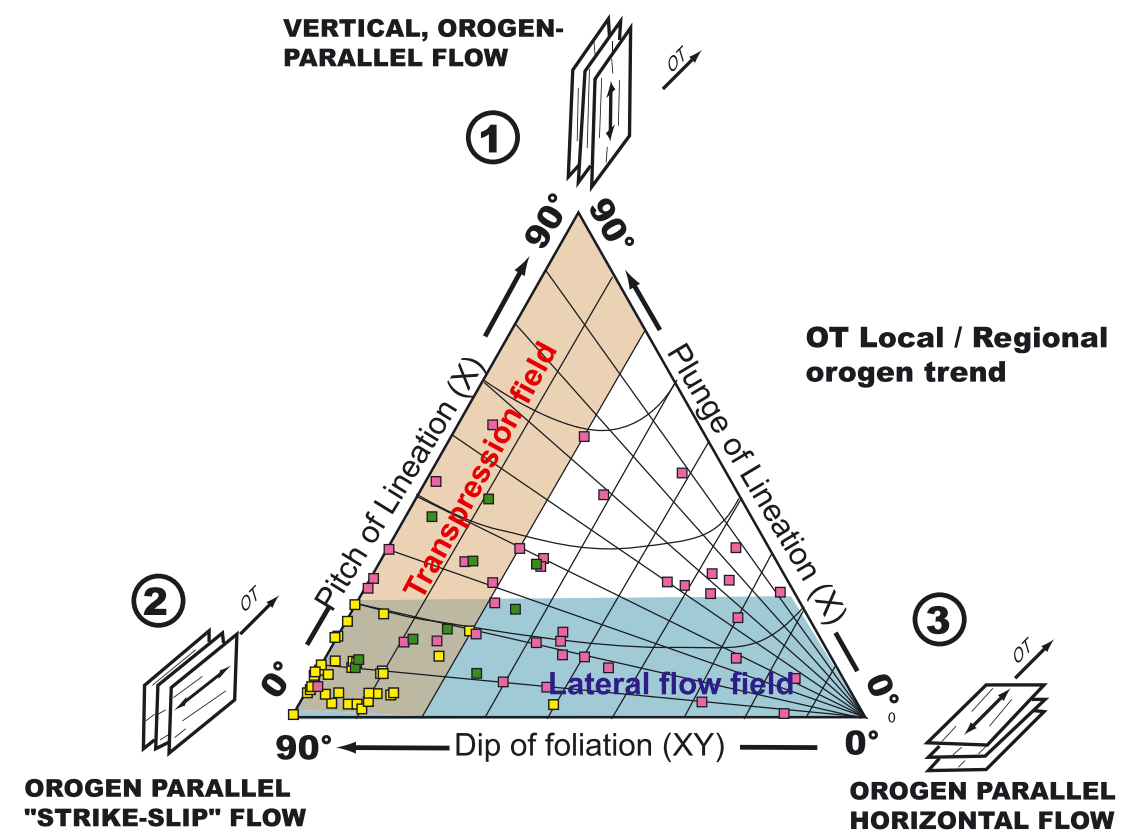

$\square$ Northern domain data ( $\mathrm{N}$ of Corz beach)

- Central domain data ( $\mathrm{N}$ of Corz beach)

$\square$ Southern domain data (S of Corz beach)

Figure 10. Fabric data plotted in the crustal flow mode diagram of Chardon et al. (2009) (using a plot concept from Balé \& Brun, 1989). Data measurements represented by squares. Structural measurements are available in the data repository archived in the website (https://perso-sdt.univ-brest.fr/ authemayou/datarepository2018TC005189R/repository). 
tangential shearing and wrenching. The compatibility and geometrical relationship among all the structures of the southern unit are interpreted as a bulk oblique to lateral flow produced by the interplay of strike-perpendicular shortening and orogen-parallel constrictional stretching (Figure 10).

\section{Discussion}

\subsection{Chronology of Ouessant Deformation}

Compiling the available age data set of syntectonic intrusive complexes in the Léon and Ouessant leads us to propose a two-stage tectonic history to the Ouessant units during Carboniferous time. In the southern and central units, the contemporaneous intrusions during the sedimentation of the micaschists being dated at $336.3 \pm 2.3$ by U-Th dating on zircon (Caroff et al., 2016; Table 1) imply that the ductile deformation of these formations must be younger than $\sim 336 \mathrm{Ma}$. This sedimentation occurred during prograde metamorphism of the Léon units (Faure et al., 2010; Le Gall et al., 2014; Schulz, 2013).

The deformation of the Ouessant southern unit is associated with NE trending dextral ductile shearing that could be correlated with the EW to NE trending dextral shear zones extending through the Léon dome and the Molene Archipelago. In the Léon dome, this dextral shearing occurred during a tectonomagmatic event in the 320- to 310-Ma time interval related to the Saint-Renan and Groac'h Zu intrusions (Le Gall et al., 2014; Figure 1c and Table 1). Microtextural evidence and metamorphic phase relations observed in Léon argue for the synchronicity between the NW trending dextral shearing, the dome exhumation, and the thermal peak of P-T paths (Jones, 1994; Le Gall et al., 2014). We therefore allocate the same time period for the first stage of deformation associated with NE trending dextral shearing recorded in the southern unit of Ouessant.

This NE trending dextral shearing event is not recorded in the northern unit of Ouessant Island, which instead records younger sinistral ductile shearing along the Northern and Central Ouessant NE trending shear zones, in the SW prolongation of the PGSZ, north of the Léon dome (Caroff et al., 2015; Figure 1c). All these shear zones are accompanied by synkinematic granitoids, the Northern Ouessant, and the Aber Ildut granites, dated at $303 \pm 5 \mathrm{Ma}$ by Rb-Sr on biotite and at $304 \pm 1$ Ma by U-Th method on zircon, respectively (Caroff et al., 2015; Leutwein et al., 1969; Figure 1c). In the Northern Ouessant granite, the existence of localized NW trending dextral ductile-brittle shear zones in tourmaline-rich pegmatites affecting the NE trending sinistral S-C fabrics suggests that sinistral shearing ended during the final stage of the magma cooling (Caroff et al., 2015).

Metamorphic and magmatic issues can also be discussed on the basis of monazite EMP-Th-U-Pb ages obtained in the Ouessant Island by Schulz (2013). The maximum monazite ages of $\sim 314 \pm 21$ Ma are not associated with any magmatic events in the Ouessant area where magmatic events are instead dated at around 336 and $304 \mathrm{Ma}$ (Caroff et al., 2015, 2016; Table 1). This HT event could represent a regional, high-temperature metamorphic event of the micaschists during the first stage of Ouessant deformation associated with NE trending dextral shearing, the latter being correlated with NE trending dextral shearing observed in the Léon dome contemporaneous with the emplacements of the Saint-Renan and Groac'h Zu intrusions of 320-310 Ma (Le Gall et al., 2014). The minimum monazite ages of $295 \pm 28$ Ma in micaschists of Ouessant could be correlated with the tectonomagmatic event that resulted in the northern Ouessant granitic complex (Lokeltas granite) at around $304 \mathrm{Ma}$ (U-Th method on zircon) synchronously to NE trending sinistral shearing (Caroff et al., 2015) (Table 1).

Cumulatively, these data suggest a two-step structural evolution of the Ouessant high-strain units at around 320-310 and $300 \mathrm{Ma}$, respectively (Figure 11). According to the change of direction of structures between the northern/central and southern units (Figure 3a), this polyphase history is associated with a clockwise rotation of the maximum shortening direction from NW-SE to N-S.

\subsection{Synorogenic Wrenching-Related Dome Exhumation}

We have seen that the southern unit was affected by NE trending dextral shearing, a NW trending orogenperpendicular shortening (contemporaneous to S1), which was progressively deformed and dominated by orogen-parallel constrictional stretching and top-to-the NE tangential shearing (contemporaneous to F2 axis). We have shown that this deformation most probably occurred during the Léon dome exhumation. 

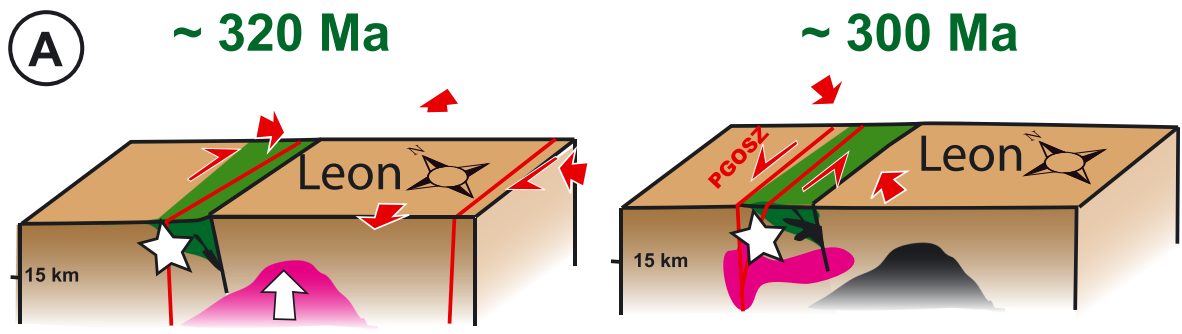

(B)

partial melting
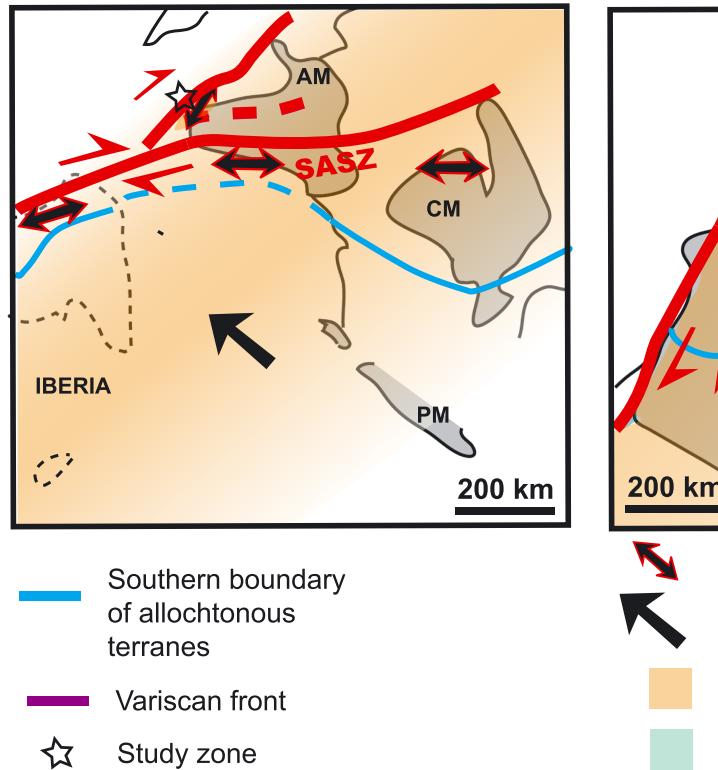

Southern boundary

of allochtonous terranes

Variscan front

Study zone

Hot lithosphere

Cold lithosphere

Figure 11. (a) Block diagrams showing the configuration of the Léon-Ouessant domains at 320-300 Ma. Magmatic units are colored pink during their emplacement and black when they are cooled. Ouessant basin in green. (b) Sketches of the Ibero-Armorican arc at around 320 and $300 \mathrm{Ma}$. AM = Amorican Massif; CM = Central Massif; PM = Pyrenean Massif; IAA = Ibero-Armorican arc; CO = Cantabrian orocline; PGOSZ = Porspoder Guissény Ouessant shear zone; SASZ = South Armorican shear zone.

The top-to-the-NE tangential shearing on NE dipping shear planes associated with NE trending dextral shearing could be interpreted as the expression of localized extension allowing dome exhumation in a wrenching context. Dextral wrenching during the Variscan collision may be favored by the obliquity of convergence between the Gondwana and Laurasia plates (Braid et al., 2011; Martínez Catalán, 2011; PastorGalán et al., 2015; Figure 11a). Alternatively, it could be produced by the impingement of an irregular Gondwana continental margin that would have increased lateral flow and wrenching by extrusion of the more ductile parts of the crust at the edges, as applied to the Himalayas (e.g., Brun \& Burg, 1982; Casas \& Murphy, 2018; Matte \& Ribeiro, 1975; Matte, 1991; Tapponnier \& Molnar, 1976; Tapponnier et al., 1986; Ribeiro et al., 1995, 2007; Figure 11a).

Dome exhumation in wrenching context could be allowed by a strike-slip releasing bend, such as a pull-apart system (Denèle et al., 2017; Rey et al., 2017) or by vertical extrusion in a transpressive zone (Billerot et al., 2017; Thompson et al., 1997). Constriction observed in our study zone could be produced in both cases, by local transtension in a pull-apart structure (e.g., Dewey et al., 1998; Fossen et al., 2013), or by a modified form of transpression that involves two perpendicular shortening axes (Dias \& Ribeiro, 1994; Duclaux et al., 2007; Solar \& Brown, 2001). In the first hypothesis (pull apart), dome exhumation generally involves localized boundary shear zones (detachment) that could lead the juxtaposition of HT rocks against low-grade supracrustral units (Roger et al., 2015). Distinct PTt records between the Léon units and Ouessant units (Figure 2a), with shallower burial depth for the Ouessant metamorphic units as compared to the Léon units (Schulz, 2013) and the existence of a time lag between the onset of deformations in the Léon dome 
(post 450-350 Ma; see Le Gall et al., 2014 for details) and in the Ouessant Island (post $336 \mathrm{Ma}$ ), are consistent with a major tectonic boundary between the Léon dome and the southern Ouessant structural unit. The drop of $\mathrm{P} / \mathrm{T}$ conditions suggests an attenuation of the metamorphic section, reflecting crustal thinning in agreement with the exhumation of the Léon dome in a pull-apart context with major tectonic boundaries. In the second hypothesis (distributed transpressive zone), horizontal shortening affecting a weak lithosphere could allow both dome exhumation associated with subvertical stretch and lateral channel flow associated with subhorizontal stretch (Cagnard et al., 2006). In southern Ouessant, the structures are interpreted as an oblique to lateral flow produced by the interplay of strike-perpendicular shortening and orogen-parallel constrictional stretching. This deformation pattern agrees with distributed transpression associating lateral flow by partitioning (Cagnard et al., 2006). Strong thermal conditions seem to be reached in the study zone because the geochemistry of volcanic products at the edge of the dome indicates that the lithosphere was already thin at $336 \mathrm{Ma}$ before deformation (Caroff et al., 2016). However, it is not to be excluded that a pull-apart system in depth is bordered by more diffuse deformation zones with shearing than the classical scheme of pull-apart structures and thus generating a deformation pattern similar to that observed on Southern Ouessant. Gneiss dome in Marbat area (southern Arabian Peninsula) was emplaced in a releasing bend along a dextral strike-slip fault system shown at its boundaries alternating corridors of various strains suggesting the interplay of dome amplification, shortening, and strike-slip shearing (Denèle et al., 2017). Therefore, the two tectonics hypotheses (diffused transpression or pull-part system) allowing the Léon dome exhumation cannot be distinguished on the basis of the Ouessant structural data and metamorphic conditions determined by previous studies. Precise mapping of the limits of the Léon dome, using new bathymetric and structural data and rigorous structural, metamorphic, and magmatic analyses of the core of the dome to highlight notably potential major subvertical stretch, is necessary to bring new constraints on this issue. The dome significance in orogeny must be evaluated by determining the thermal-mechanical relationship between doming, P-T paths, and melting and by documenting the structural relationship among domes, subdomes, and mantling rocks (Whitney et al., 2004).

Apart from the tectonic processes, especially at convergent plate boundaries (Vanderhaeghe, 2012), other mechanisms enhancing dome exhumation can be mentioned such as (i) erosion during crustal thickening (Beaumont et al., 2001, 2006), (ii) isostatic forcing, (iii) the role of buoyancy forces produced by crustal thickness contrasts and indenter effect (England \& McKenzie, 1982) or synchronous crustal melting (Thompson, 1999; Vanderhaeghe, 2009). The Léon dome is cored by migmatites (metatexites from former partially molten rocks; Figure 1c). U-Th/Pb dating on monazite in situ by the EPMA method on metatexites gave ages in the range 340-297 Ma (Faure et al., 2010; Marcoux et al., 2009; Table 1). Though the precise meaning of these ages is not detailed in the literature (prograde metamorphism and the stage of melting, of cooling, or of crystallization), this time period is consistent with the chronology of dome exhumation (i.e., 320-310 Ma) established from tectonomagmatic constraints (Jones, 1994; Le Gall et al., 2014; Schulz, 2013) and allows us to propose the buoyancy forces as a potential aide to the Léon dome exhumation. In addition, dome exhumation might have been enhanced by isostatic forcing with regard to the high thermal conditions suggested by previous authors in the study area (Caroff et al., 2016).

\subsection{Cold Extrusion During the Ibero-Armorican Bending}

At around $300 \mathrm{Ma}$, the Léon and Ouessant structural units were affected by a final magmatic event that led to the emplacement of the Aber-Ildut/North Ouessant synkinematic granitoid complex along the sinistral PGSZ (Caroff et al., 2015; Chauris, 1994) and its SW extension along the Ouessant shear zones (Figure 1c). The so-called Porspoder Guissény Ouessant shear zone (PGOSZ) is a narrow ( $<2 \mathrm{~km}$ wide) major shear zone associated with a granitic complex that extends $\mathrm{N} 60^{\circ} \mathrm{E}$ over more than $60 \mathrm{~km}$, up to Brignogan, where sinistral shearing is no longer identified. The geochemistry of this young granitic belt indicates the upward migration of mantle-derived melts through this fundamental Armorican discontinuity into a thinned lithosphere (Caroff et al., 2015). In its alignment, late orogenic granites outcrop through the Northern boundary of the Northern Armorican cratonic crust, over more than $300 \mathrm{~km}$ up to the Barfleur granite in Normandy (Chauris, 1991). At the same time, dextral displacement occurred along the N110- $120^{\circ}$ E trending South Armorican Shear Zone (SASZ; e.g., Augier et al., 2015), between the rigid Central Armorican domain and the weakened South Armorican crust that experienced orogen-parallel extension, thinning, and exhumation of migmatitic units (e.g., Gapais et al., 2015; Figures 1b and 11b). Therefore, it appears that at $300 \mathrm{Ma}$, the $\mathrm{N} 60^{\circ} \mathrm{E}$ sinistral PGOSZ and the $\mathrm{N} 110^{\circ} \mathrm{E}$ dextral SASZ acted as 
a conjugate shear pattern on both sides of the rigid Léon, the North and Central Armorican domains, in response to N-S trending maximum shortening (Gumiaux et al., 2004; this study; Figure 11b). The contemporaneous sinistral Pont l'Abbé shear zone, SW of the SASZ, could also play the same role as a conjugate shear zone with regard to the western prolongation of the SASZ, accommodating the extrusion of another rigid block (Figure 11b).

This NS trending maximum shortening at 300 Ma could be produced by the Gondwana continental indenter within the Ibero-Armorican arc (Casas \& Murphy, 2018; Ribeiro et al., 1995, 2007) (Figure 11b). Llana-Fúnez and Marco (2007) proposed that this process was triggered by a contrast in upper crust thickness across the orogen, with marked thickening in the core of the arc by the Cantabrian orocline buckling and thinning in the external region. Gutiérrez-Alonso et al. (2012) suggested that buckling involves asthenosphere-lithosphere interactions producing delamination or thermal erosion. These processes imply the soft character of the surrounding lithosphere that is able to escape from the closing structure by lateral flow along the branches of the arc, for example, along the North Pyrenean shear zone or the SASZ (Augier et al., 2015; Cochelin et al., 2017; Gapais et al., 2015; Llana-Fúnez \& Marco, 2007). From that point of view, the SASZ could have acted as a transfer zone between the cold Central Armorican domain and the hot South Armorican domain (Gapais et al., 2015), in a manner similar to other arcuate belts like the Aegean, the Apennine-Calabria, and the Rif-Gibraltar-Betics regions (Brun \& Faccenna, 2008; Faccenna et al., 2004; Palano et al., 2017; Rutter \& Valetti, 2019). We propose to add to this kinematic model a component of lateral escape further north, in the more external rigid domains, by extrusion of the Léon-Central-North Armorican wedge via a conjugate network of strike-slip ductile shear zones (dextral SASZ and sinistral PGOSZ; Figure 11b).

\section{Conclusion}

Structural analysis of ductilely deformed micaschists, orthogneisses, and syntectonic plutons at the northwestern boundary of the Léon dome, to the west of the Armorican massif, affecting Variscan units on the Ouessant Island, suggests two stages of deformation at $\sim 320$ and $\sim 300$ Ma recorded to the south and to the north of the island, respectively. The southern zone shows a steeply or gently dipping pervasive schistosity associated with crenulation parallel to a $\mathrm{N} 70^{\circ} \mathrm{E}$ trending stretching lineation and E-W trending subvertical dextral shear zones. This overall strain pattern is temporally correlated with exhumation of migmatitic gneisses, further east, in the core of the Léon dome at 330-310 Ma. The southern zone of Ouessant behaved as a tectonic boundary that accommodated dome exhumation with a wrenching component during the Variscan oblique convergence. Subsequently, the northern zone of Ouessant localized NE trending sinistral ductile shearing, coeval with the intrusion of a granitoid complex at 300 Ma. The North Ouessant sinistral shear zone is part of a regional-scale discontinuity at the northern boundary of the Léon-North-Central Armorican crustal block. Its association with the dextral SASZ resulted in a conjugate shear pattern that accommodated lateral escape of the block during amplification of the Ibero-Amorican arc at 300 Ma, in turn produced by the buckling and subsequent indentation of the Cantabrian orocline in North Iberia and as a result, the orogenic syntax bending. The northern Léon boundary located on the Ouessant Island is a major long-term Variscan wrenching structure that played various roles during orogeny. Future studies should supply new P-T constraints on the shear deformations and age constraints of wrenching with respect to dome exhumation to confirm the proposed scenario.

Acknowledgments

This work was carried out in the laboratory of Oceanic Geosciences in Brest. We greatly thank Dominique Chardon, Christian Teyssier, Pierre Trapp, Bernhard Schulz, Olivier Vanderhaeghe, Gianluca Vignaroli, the anonymous reviewers, and the Associated Editor, Federico Rossetti, for his helpful advice, and Bryan Cochelin for his help on the structural data management. All the data used are listed in the references or archived online (https://perso-sdt.univ-brest.fr/ authemayou/datarepository2018TC 005189R/repository).

\section{References}

Arthaud, F., \& Matte, P. (1977). Late Paleozoic strike-slip faulting in southern Europe and northern Africa: Result of a right-lateral shear zone between the Appalachians and the Urals. Geological Society of America Bulletin, 88(9), 1305-1320. https://doi.org/10.1130/00167606(1977)88<1305:LPSFIS > 2.0.CO;2

Augier, R., Choulet, F., Faure, M., \& Turrillot, P. (2015). A turning-point in the evolution of the Variscan orogen: The ca. 325 Ma regional partial melting event of the coastal South Armorican domain (South Brittany and Vendée, France). Bulletin de la Societe Géologique de France, 186(2-3), 63-91. https://doi.org/10.2113/gssgfbull.186.2-3.63

Balé, P., \& Brun, J. P. (1989). Late Precambrian thrust and wrench zones in northern Brittany (France). Journal of Structural Geology, 11(4), 391-405. https://doi.org/10.1016/0191-8141(89)90017-5

Balé, P., \& Brun, J.-P. (1986). Les complexes métamorphiques du Léon (NW Bretagne): Un segment dun domaine éo-hercynien sud armoricain translaté au Dévonien. Bulletin de la Société Géologique de France, 2(3), 471-477.

Ballèvre, M., Bosse, V., Ducassou, C., \& Pitra, P. (2009). Palaeozoic history of the Armorican massif: Models for the tectonic evolution of the suture zone. Comptes Rendus Geosciences, 341(2-3), 174-201. https://doi.org/10.1016/j.crte.2008.11.009 
Beaumont, C., Jamieson, R. A., Nguyen, M. H., \& Lee, B. (2001). Himalayan tectonics explained by extrusion of a low-viscosity crustal channel coupled to focused surface denudation. Nature, 414(6865), 738-742. https://doi.org/10.1038/414738a

Beaumont, C., Nguyen, M. H., Jamieson, R. A., \& Ellis, S. (2006). Crustal flow modes in large hot orogens. Geological Society, London, Special Publications, 268(1), 91-145. https://doi.org/10.1144/GSL.SP.2006.268.01.05

Billerot, A., Duchene, S., Vanderhaeghe, O., \& de Sigoyer, J. (2017). Gneiss domes of the Danba Metamorphic Complex, Songpan Ganze, eastern Tibet. Journal of Asian Earth Sciences, 140, 48-74. https://doi.org/10.1016/j.jseaes.2017.03.006

Bioret, F., David, L., Darboux, J.-R., Gourmelon, F., Guermeur, Y., Hallégouët, B., et al. (2012). Ouessant. Atlas environmental. ISBN: 978-29534262-3-6. Les cahiers du CEMO, 4. hal-00797158.

Bird, P. (1991). Lateral extrusion of lower crust from under high topography in the isostatic limit. Journal of Geophysical Research, 96(B6), 10,275-10,286. https://doi.org/10.1029/91JB00370

Braid, J. A., Murphy, J. B., Quesada, C., \& Mortensen, J. (2011). Tectonic escape of a crustal fragment during the closure of the Rheic Ocean: $\mathrm{U}-\mathrm{Pb}$ detrital zircon data from the late Palaeozoic Pulo Do Lobo and South Portuguese Zones, southern Iberia. Journal of the Geological Society, London, 168(2), 383-392. https://doi.org/10.1144/0016-76492010-104

Brooks, E. R., Wood, M. M., \& Garbutt, P. L. (1982). Origin and metamorphism of peperite and associated rocks in the Devonian Elwell Formation, northern Sierra Nevada, California. Geological Society of America Bulletin, 93, 1208-1231.

Brun, J.-P., \& Burg, J.-P. (1982). Combined thrusting and wrenching in the Ibero-Armorican arc: A corner effect during continental collision. Earth and Planetary Science Letters, 61(2), 319-332. https://doi.org/10.1016/0012-821X(82)90063-2

Brun, J.-P., \& Faccenna, C. (2008). Exhumation of high-pressure rocks driven by slab rollback. Earth and Planetary Science Letters, 272(1-2), 1-7. https://doi.org/10.1016/j.epsl.2008.02.038

Burg, J. P., Bale, P., Brun, J. P., \& Girardeau, J. (1987). Stretching lineation and transport direction in the Ibero-Armorican arc during the Siluro-Devonian collision. Geodinamica Acta, 1(1), 71-87. https://doi.org/10.1080/09853111.1987.11105126

Burg, J. P., Kaus, B. J., \& Podladchikov, Y. Y. (2004). Dome structures in collision orogens: Mechanical investigation of the gravity/compression interplay. In Gneiss Domes in Orogeny, Special Papers, Geological Society of America, (pp. 47-66).

Burg, J.-P., \& Podladchikov, Y. (2000). From buckling to asymmetric folding of the continental lithosphere: Numerical modelling and application to the Himalayan syntaxes. Geological Society, London, Special Publications, 170(1), 219-236. https://doi.org/10.1144/GSL. SP.2000.170.01.12

Burg, J. P., Van Den Driessche, J., \& Brun, J. P. (1994). Syn- to post-thickening extension: Mode and structural consequences. Comptes rendus de l'Académie des sciences. Série 2, 319(9), 1019-1032.

Cabanis, B., \& Godard, G. (1987). Les éclogites du pays de Léon (Nord-Ouest du Massif armoricain): Étude pétrologique et géochimique; implications géodynamiques. Bulletin de la Société Géologique de France, 3(6), 1133-1142.

Cagnard, F., Durrieu, N., Gapais, D., Brun, J. P., \& Ehlers, C. (2006). Crustal thickening and lateral flow during compression of hot lithospheres, with particular reference to Precambrian times. Terra Nova, 18(1), 72-78. https://doi.org/10.1111/j.13653121.2005.00665.x

Caroff, M., Labry, C., Le Gall, B., Authemayou, C., Bussien Grosjean, D., \& Guillong, M. (2015). Petrogenesis of late-Variscan high-K alkalicalcic granitoids and calcalkalic lamprophyres: The Aber-Ildut/North-Ouessant complex, Armorican massif, France. Lithos, 238, 140-155. https://doi.org/10.1016/j.lithos.2015.09.025

Caroff, M., Le Gall, B., Authemayou, C., Bussien Grosjean, D., Labry, C., \& Guillong, M. (2016). Relations between basalts and adakiticfelsic intrusive bodies in a soft-substrate environment: The South Ouessant Visean basin in the Variscan belt, Armorican Massif, France. Canadian Journal of Earth Sciences, 53(4), 441-456. https://doi.org/10.1139/cjes-2015-0230

Casas, J. M., \& Murphy, J. B. (2018). Unfolding the arc: The use of pre-orogenic constraints to assess the evolution of the Variscan belt in Western Europe. Tectonophysics, 736, 47-61. https://doi.org/10.1016/j.tecto.2018.04.012

Chantraine, J., Chauris, L., Cabanis, B., Chauris, M.-M., Larsonneur, C., Herrouin, Y., et al. (1986). Notice explicative de la feuille Plestinles-Grèves à 1/50 000. Éd. Bureau Recherche Géologique et Minière: 64 p., Orléans.

Chardon, D., Gapais, D., \& Cagnard, F. (2009). Flow of ultra-hot orogens: A view from the Precambrian, clues for the Phanerozoic. Tectonophysics, 477(3-4), 105-118. https://doi.org/10.1016/j.tecto.2009.03.008

Chauris, L. (1991). Le granite porphyroïde de Porzpaul dans l'île d'Ouessant: Un nouvel element dans la ceinture des "granites rouges" du Massif armoricain (France). Comptes rendus de l'Académie des Sciences. Série, 2(313), 245-250.

Chauris, L. (1994). Notice explicative, Carte géologique de la France (1/50 000), Notice explicative de la feuille Plouarzel-île d'Ouessant à 1/50 000 (237). Orléans, BRGM Éditions.

Chauris, L., \& Hallégouët. B. (1989). Notice explicative de la feuille Le Conquet à 1/50000, BRGM, Service Géologique National, Orléans

Cochelin, B., Chardon, D., Denèle, Y., Gumiaux, C., \& Le Bayon, B. (2017). Vertical strain partitioning in hot Variscan crust: Syn-convergence escape of the Pyrenees in the Iberian-Armorican syntax. Bulletin de la Société Géologique de France, 188(6), 39. https://doi.org/ $10.1051 / \mathrm{bsgf} / 2017206$

Darboux, J. R., \& Le Gall, B. (1988). Les Montagnes Noires: Cisaillement bordier méridional du bassin carbonifère de Châteaulin (Massif armoricain, France). Caractéristiques structurales et métamorphiques. Geodinamica Acta, 2(3), 121-133. https://doi.org/10.1080/ 09853111.1988 .11105161

Denèle, Y., Olivier, P., Gleizes, G., \& Barbey, P. (2007). The Hospitalet gneiss dome (Pyrenees) revisited: Lateral flow during Variscan transpression in the middle crust. Terra Nova, 19(6), 445-453. https://doi.org/10.1111/j.1365-3121.2007.00770.x

Denèle, Y., Olivier, P., Gleizes, G., \& Barbey, P. (2009). Decoupling between the middle and upper crust during transpression-related lateral flow: Variscan evolution of the Aston gneiss dome (Pyrenees, France). Tectonophysics, 477(3-4), 244-261. https://doi.org/10.1016/j. tecto.2009.04.033

Denèle, Y., Roques, D., Ganne, J., Chardon, D., Rousse, S., \& Barbey, P. (2017). Strike-slip metamorphic core complexes: Gneiss domes emplaced in releasing bends. Geology, 45(10), 903-906. https://doi.org/10.1130/G39065.1

DePaolo, D. J., \& Wasserburg, G. J. (1976). Nd isotopic variations and petrogenetic models. Geophysical Research Letters, 3(5), 249-252. https://doi.org/10.1029/GL003i005p00249

Dewey, J. F., Holdsworth, R. E., \& Strachan, R. A. (1998). Transpression and transtension zones. In R. Holdsworth, R. E. Strachan, \& R. A. Dewey (Eds.), Continental Transpressional and Transtensional Tectonics, Special Publications, (Vol. 135, pp. 1-14). London: Geological Society. https://doi.org/10.1144/GSL.SP.1998.135.01.01.

Dias, R., \& Ribeiro, A. (1994). Constriction in a transpressive regime: An example in the Iberian branch of the Ibero-Armorican arc. Journal of Structural Geology, 16(11), 1543-1554. https://doi.org/10.1016/0191-8141(94)90032-9

Dias, R., \& Ribeiro, A. (1995). The Ibero-Armorican Arc-A collision effect against an irregular continent. Tectonophysics, 246(1-3), 113-128. https://doi.org/10.1016/0040-1951(94)00253-6 
Duclaux, G., Rey, P., Guillot, S., \& Ménot, R. P. (2007). Orogen-parallel flow during continental convergence: Numerical experiments and Archean field examples. Geology, 35(8), 715-718. https://doi.org/10.1130/G23540A.1

Echtler, H., \& Malavieille, J. (1990). Extensional tectonics, basement uplift and Stephano-Permian collapse basin in a late Variscan metamorphic core complex. Tectonophysics, 177(1-3), 125-138. https://doi.org/10.1016/0040-1951(90)90277-F

Edel, J. B., Schulmann, K., Lexa, O., Diraison, M., \& Géraud, Y. (2015). Permian clockwise rotations of the Ebro and Corso-Sardinian blocks during Iberian-Armorican oroclinal bending: Preliminary paleomagnetic data from the Catalan Coastal Range (NE Spain). Tectonophysics, 657, 172-186. https://doi.org/10.1016/j.tecto.2015.07.002

England, P., \& McKenzie, D. (1982). A thin viscous sheet model for continental deformation. Geophysical Journal International, 70(2), 295-321. https://doi.org/10.1111/j.1365-246X.1982.tb04969.x

Faccenna, C., Piromallo, C., Crespo-blanc, A., Jolivet, L., \& Rossetti, F. (2004). Lateral slab deformation and the origin of the western Mediterranean arcs. Tectonics, 23, TC1012. https://doi.org/10.1029/2002TC001488

Faure, M., Bé Mézème, E., Duguet, M., Cartier, C., \& Talbot, J.-Y. (2005). Paleozoic tectonic evolution of Medio-Europa from the example of the French Massif Central and Massif Armoricain. In R. Carosi, R. Dias, D. Iacopini, \& G. Rosenbaum (Eds.), The southern Variscan Belt, J. Virtual Explor., (electron ed., Vol. 19, pp. 1-25). http://virtualexplorer.com.au

Faure, M., Sommers, C., Meleton, J., Cocherie, A., \& Lautut, O. (2010). The Léon Domain (French Massif Armoricain): A westward extension of the Mid-German Crystalline Rise? Structural and geochronological insights. International Journal of Earth Sciences, 99(1), 65-81. https://doi.org/10.1007/s00531-008-0360-x

Fossen, H., Cavalcante, G. C. G., Pinheiro, R. V. L., \& Archanjo, C. J. (2018). Deformation—Progressive or multiphase? Journal of Structural Geology, 125, 82-99.

Fossen, H., Teyssier, C., \& Whitney, D. L. (2013). Transtensional folding. Journal of Structural Geology, 56, 89-102. https://doi.org/10.1016/j jsg.2013.09.004

Franke, F., Cocks, L. R. M., \& Torsvik, T. H. (2017). The Palaeozoic Variscan oceans revisited. Gondwana Research, 48, 257-284. https://doi. org/10.1016/j.gr.2017.03.005

Franke, W. (2012). Comment on Dörr and Zulauf: Elevator tectonics and orogenic collapse of a Tibetan-style plateau in the European Variscides: The role of the Bohemian shear zone. Int J Earth Sci (Geol Rundsch)(2010) 99: 299-325. International Journal of Earth Sciences, 101(7), 2027-2034. https://doi.org/10.1007/s00531-012-0766-3

Franke, W. (2014). Topography of the Variscan orogen in Europe: Failed-Not collapsed. International Journal of Earth Sciences, 103(5), 1471-1499. https://doi.org/10.1007/s00531-014-1014-9

Freund, R. (1974). Kinematics of transform and transcurrent faults. Tectonophysics, 21(1-2), 93-134. https://doi.org/10.1016/0040-1951(74) 90064-X

Gapais, D., Brun, J.-P., Gumiaux, C., Cagnard, F., Ruffet, G., \& Veslud, C. L. C. D. (2015). Extensional tectonics in the Hercynian Armorican belt (France). An overview. Bulletin de la Société Géologique de France, 186(2-3), 117-129. https://doi.org/10.2113/gssgfbull.186.2-3.117

Gapais, D., Cagnard, F., Gueydan, F., Barbey, P., \& Ballèvre, M. (2009). Mountain building and exhumation processes through time: Inferences from nature and models. Terra Nova, 21(3), 188-194. https://doi.org/10.1111/j.1365-3121.2009.00873.x

Gapais, D., \& Le Corre, C. (1980). Is the Hercynien belt of Brittany a major shear zone? Nature, 288(5791), 574-576. https://doi.org/10.1038/ $288574 \mathrm{a} 0$

Genser, J., \& Neubauer, F. (1989). Low angle normal faults at the eastern margin of the Tauern window (Eastern Alps). Mitteilungen der Österreichischen Geologischen Gesellschaft, 81(1988), 233-243.

Georget, Y., Martineau, F., \& Capdevila, R. (1986). Âge tardi-hercynien et origine crustale du granite de Brignogan (Finistère, France). Conséquences sur l'interprétation des granites nord-armoricains. Comptes Rendus de l'Académie des Sciences de Paris, 302(II), 237-242.

Godard, G., \& Mabit, J.-L. (1998). Peraluminous sapphirine formed during retrogression of a kyanite-bearing eclogite from Pays de Léon, Armorican Massif, France. Lithos, 43(1), 15-29. https://doi.org/10.1016/S0024-4937(98)00004-8

Goré, B., \& Le Corre, C. (1987). Cinématique hercynienne du cisaillement nord-armoricain à la bordure du granite syntectonique de Saint Renan-Kersaint (Finistère). Bulletin de la Société Géologique de France, 3(5), 811-819.

Gumiaux, C., Gapais, D., Brun, J.-P., Chantraine, J., \& Ruffet, G. (2004). Tectonic history of the Hercynian Armorican Shear Belt (Brittany, France). Geodinamica Acta, 17(4), 289-307. https://doi.org/10.3166/ga.17.289-307

Gutiérrez-Alonso, G., Johnston, S. T., Weil, A. B., Pastor-Galán, D., \& Fernández-Suárez, J. (2012). Buckling an orogen: The Cantabrian Orocline. GSA Today, 22(7), 4-9.

Harland, W. B. (1971). Tectonic transpression in caledonian Spitsbergen. Geological Magazine, 108(1), 27-41. https://doi.org/10.1017/ S0016756800050937

Jolivet, L., De Lamotte, D. F., Mascle, A., \& Séranne, M. (1999). The Mediterranean basins: Tertiary extension within the Alpine orogenAn introduction. Geological Society, London, Special Publications, 156(1), 1-14. https://doi.org/10.1144/GSL.SP.1999.156.01.02

Jones, K. A. (1993). Phase relations in Al2SiO5 polymorphs; Le Conquet region, North-Western Brittany, France. Proceedings. Ussher Society, 8(2), 138-144.

Jones, K. A. (1994). Progressive metamorphism in a crustal-scale shear zone: An example from the Léon region, north-west Brittany, France. Journal of Metamorphic Geology, 12(1), 69-88. https://doi.org/10.1111/j.1525-1314.1994.tb00004.x

Kroner, U., \& Romer, R. L. (2013). Two plates-Many subduction zones: The Variscan orogeny reconsidered. Gondwana Research, 24(1), 298-329. https://doi.org/10.1016/j.gr.2013.03.001

Le Corre, C., Bale, P., \& Georget, Y. (1989). Le Léon: Un domaine exotique au Nord-Ouest de la chaine varisque armoricaine (France). Geodinamica Acta, 3, 57-71.

Le Gall, B. (1990). Evidence of an imbricate crustal thrust belt in the Southern British Variscides. Contributions of Southwestern Approaches Traverse (SWAT) deep seismic reflection profiling recorded through the English Chanel and the Celtic Sea. Tectonics, 9(2), 283-302. https://doi.org/10.1029/TC009i002p00283

Le Gall, B., Authemayou, C., Ehrhold, A., Paquette, J.-L., Bussien, D., Chazot, G., et al. (2014). LiDAR offshore structural mapping and U/Pb zircon/monazite dating of Variscan strain in the Léon metamorphic domain, NW Brittany. Tectonophysics, 630, 236-250. https://doi.org/ 10.1016/j.tecto.2014.05.026

Le Gall, B., Loboziak, S., \& Le Herisse, A. (1992). Le franc sud du synclinorium carbonifere de Chateaulin (Massif armoricain, France): Une bordure de bassin reactive en contexte decro-chevauchant. Bulletin de la Société Géologique de France, 163, 13-26.

Le Hérissé, A., \& Plaine, J. (1982). Volcanisme basique dans le Carbonifère inférieur du Synclinorium de Laval (Massif armoricain, France). Comptes Rendus de l'Académie des Sciences, Paris, II(294), 1199-1202.

Le Pourhiet, L., Huet, B., May, D. A., Labrousse, L., \& Jolivet, L. (2012). Kinematic interpretation of the 3D shapes of metamorphic core complexes. Geochemistry, Geophysics, Geosystems, 13, Q09002. https://doi.org/10.1029/2012GC004271 
Leutwein, F., Chauris, L., Sonet, J., \& Zimmermann, J.-L. (1969). Etudes géochroniques et géotectoniques dans le Nord-Finistère. Bulletin Sciences de la Terre, 14/44, 331-358.

Lister, G. S., \& Snoke, A. W. (1984). SC mylonites. Journal of Structural Geology, 6(6), 617-638.

Llana-Fúnez, S., \& Marco, A. (2007). Convergence in a thermally softened thick crust: Variscan intracontinental tectonics in Iberian plate rocks. Terra Nova, 19(6), 393-400. https://doi.org/10.1111/j.1365-3121.2007.00763.x

Mahéo, G., Pêcher, A., Guillot, S., Rolland, Y., \& Delacourt, C. (2004). Exhumation of Neogene gneiss domes between oblique crustal boundaries in south Karakorum (northwest Himalaya, Pakistan). In Gneiss Domes in Orogeny, Special Papers, (pp. 141-154). Boulder, CO: Geological Society of America.

Marcoux, E., Cocherie, A., Ruffet, G., Darboux, J. R., \& Guerrot, C. (2009). Géochronologie revisée du dôme du Léon. Géologie de la France, $1,19-40$.

Martínez Catalán, J. R. (2011). Are the oroclines of the Variscan belt related to late Variscan strike-slip tectonics? Terra Nova, 23, 241-247. https://doi.org/10.1111/j.1365-3121.2011.01005.x

Matte, P. (1986). La chaîne varisque parmi les chaînes paléozoïques péri-atlantiques: Modèle d'évolution et position des grands blocs continentaux au Permo-Carbonifère. Bulletin de la Société Géologique de France, II, 9-24.

Matte, P. (1991). Accretionary history and crustal evolution of the Variscan belt in western Europe. Tectonophysics, 196(3-4), 309-337. https://doi.org/10.1016/0040-1951(91)90328-P

Matte, P. (2001). The Variscan collage and orogeny (480-290 Ma) and the tectonic definition of the Armorica microplate: A review. Terra Nova, 13(2), 122-128. https://doi.org/10.1046/j.1365-3121.2001.00327.x

Matte, P., \& Ribeiro, A. (1975). Forme et réorientation de l'ellipsoïde de déformation dans la virgation hercynienne de Galice. Relations avec le plissement et hypothèses sur la genèse de l'arc ibéro-armorican. Comptes Rendus de l'Académie des Sciences, Paris, 280, 2825-2828.

McKenzie, D., \& Jackson, J. (1986). A block model of distributed deformation by faulting. Journal of the Geological Society, London, 143(2), 349-353. https://doi.org/10.1144/gsjgs.143.2.0349

Murphy, J. B., Quesada, C., Gutiérrez-Alonso, G., Johnston, S. T., \& Weil, A. (2016). Reconciling competing models for the tectono-stratigraphic zonation of the Variscan orogen in Western Europe. Tectonophysics, 681, 209-219. https://doi.org/10.1016/j.tecto.2016.01.006

Murphy, M. A., \& Copeland, P. (2005). Transtensional deformation in the central Himalaya and its role in accommodating growth of the Himalayan orogen. Tectonics, 24, TC4012. https://doi.org/10.1029/2004TC001659

Palano, M., Piromallo, C., \& Chiarabba, C. (2017). Surface imprint of toroidal flow at retreating slab edges: The first geodetic evidence in the Calabrian subduction system. Geophysical Research Letters, 44, 845-853. https://doi.org/10.1002/2016GL071452

Paquette, J.-L., Balé, P., Ballèvre, M., \& Georget, Y. (1987). Géochronologie et géochimie des éclogites du Léon: Nouvelles contraintes sur l'evolution géodynamique du Nord-Ouest du Massif Armoricain. Bulletin de Minéralogie, 110(6), 683-696. https://doi.org/10.3406/ bulmi.1987.8012

Pastor-Galán, D., Groenewegen, T., Brouwer, D., Krijgsman, W., \& Dekkers, M. J. (2015). One or two oroclines in the Variscan orogen of Iberia? Implications for Pangea amalgamation. Geology, 43(6), 527-530. https://doi.org/10.1130/G36701.1

Pêcher, A., \& Le Fort, P. (1999). Late Miocene tectonic evolution of the Karakorum-Nanga Parbat contact zone (northern Pakistan). In A Macfarlane, R. B. Sorkhabi, \& J. Quade (Eds.), Himalaya and Tibet: Mountain Roots to Mountain Tops, Special Papers, (pp. 145-158). America: Geological Society.

Pelhate, A. (1994). The Variscan-Carboniferous of the Armorican Massif. In J. D. Keppie (Ed.), Pre-Mesozoic Geology in France and related areas, (pp. 162-168). Berlin: Springer-Verlag. https://doi.org/10.1007/978-3-642-84915-2_14

Perroud, H., \& Bonhommet, N. (1981). Palaeomagnetism of the Ibero-Armorican arc and the Hercynian orogeny in Western Europe. Nature, 292(5822), 445-448. https://doi.org/10.1038/292445a0

Philippon, M., \& Corti, G. (2016). Obliquity along plate boundaries. Tectonophysics, 693, 171-182. https://doi.org/10.1016/j. tecto.2016.05.033

Quesada, C. (1991). Geological constraints on the Paleozoic tectonic evolution of tectonostratigraphic terranes in the Iberian Massif. Tectonophysics, 185(3-4), 225-245. https://doi.org/10.1016/0040-1951(91)90446-Y

Rabin, M., Trap, P., Carry, N., Fréville, K., Cenki-Tok, B., Lobjoie, C., et al. (2015). Strain partitioning along the anatectic front in the Variscan Montagne Noire massif (southern French Massif Central). Tectonics, 34, 1709-1735. https://doi.org/10.1002/2014TC003790

Ratschbacher, L., Frisch, W., Linzer, H. G., \& Merle, O. (1991). Lateral extrusion in the Eastern Alps. Part 2: Structural analysis. Tectonics, 10(2), 257-271. https://doi.org/10.1029/90TC02623

Rey, P. F., Mondy, L., Duclaux, G., Teyssier, C., Whitney, D. L., Bocher, M., \& Prigent, C. (2017). The origin of contractional structures in extensional gneiss domes. Geology, 45(3), 263-266. https://doi.org/10.1130/G38595.1

Ribeiro, A., Dias, R., \& Silva, J. B. (1995). Genesis of the Ibero-Armorican arc. Geodinamica Acta, 8(4), 173-184. https://doi.org/10.1080/ 09853111.1995.11417255

Ribeiro, A., Munhá, J., Dias, R., Mateus, A., Fonseca, P., Pereira, E., et al. (2009). Mechanics of thick-skinned Variscan overprinting of Cadomian basement (Iberian Variscides). Comptes Rendus Geosciences, 341(2-3), 127-139. https://doi.org/10.1016/j.crte.2008.12.003

Ribeiro, A., Munhá, J., Dias, R., Mateus, A., Pereira, E., Ribeiro, L., et al. (2007). Geodynamic evolution of SW Europe Variscides. Tectonics, 26, TC6009. https://doi.org/10.1029/2006TC002058

Roger, F., Teyssier, C., Respaut, J.-P., Rey, P. F., Jolivet, M., Whitney, D. L., et al. (2015). Timing of formation and exhumation of the Montagne Noire double dome, French Massif Central. Tectonophysics, 640-641, 53-69. https://doi.org/10.1016/j.tecto.2014.12.002

Rolet, J. (1984). Grabens losangiques (pull-apart) en régime de décrochement. Le rôle des coulissements hercyniens dans l'individualisation des bassins carbonifères du Massif armoricain. Annales de la Société Géologique du Nord, 103, 209-220.

Rolet, J., Gresselin, F., Jegouzo, P., Ledru, P., \& Wyns, R. (1994). Intracontinental hercynian events in the Armorican Massif. In PreMesozoic geology in France and related areas, (pp. 195-219). Berlin, Heidelberg: Springer. https://doi.org/10.1007/978-3-642-84915-2_20

Rolet, J., Le Gall, B., Darboux, J. R., Thonon, P., \& Gravelle, M. (1986). L'évolution géodynamique dévono-carbonifère de l'extrémité occidentale de la chaîne hercynienne d'Europe sur le transect Armorique-Cornwall. Bulletin de la Société Géologique de France, 2(1), 43-54

Royden, L. H., Burchfiel, B. C., \& van der Hilst, R. D. (2008). The geological evolution of the Tibetan Plateau. Sciences, 321(5892), 1054-1058. https://doi.org/10.1126/science.1155371

Rutter, E. H., \& Valetti, L. (2019). Stretching transforms-Mediterranean examples from the Betic-Alborán, Tyrrhenian-Calabrian and Aegean-Anatolia regions. In Transform Plate Boundaries and Fracture Zones, (pp. 301-320). Elsevier. https://doi.org/10.1016/B978-0-12812064-4.00012-8

Sanderson, D. J., \& Marchini, W. R. D. (1984). Transpression. Journal of Structural Geology, 6(5), 449-458. https://doi.org/10.1016/01918141(84)90058-0 
Schneider, D. A., Zeitler, P. K., Kidd, W. S. F., \& Edwards, M. A. (2001). Geochronologic constraints on the tectonic evolution and exhumation of Nanga Parbat, western Himalaya syntaxis, revisited. The Journal of Geology, 109(5), 563-583. https://doi.org/10.1086/322764

Schulz, B. (2013). Monazite EMP-Th-U/Pb age pattern in Variscan metamorphic units in the Armorican Massif (Brittany, France). Zeitschrift der Deutschen Gesellschaft für Geowissenschaften, 164(2), 313-335. https://doi.org/10.1127/1860-1804/2013/0008

Schulz, B., Krenn, E., Finger, F., Bratz, H., \& Klemd, R. (2007). Cadomian and Variscan metamorphic events in the Léon domain (Armorican massif, France): P-T data and EMP monazite dating. In U. Linneman, R. Nance, \& P. Kraft (Eds.), The evolution of the Rheic Ocean from Avalonian-Cadomian active margin to Alleghenian-Variscan collision, Special Papers (Vol. 423, pp. 267-285). America: Geological Society.

Şengör, A. M. C., Görür, N., \& Şaroğlu, F. (1985). Strike-slip faulting and related basin formation in zones of tectonic escape: Turkey as a case study. In K. T., Biddle, \& N. Christie-Blick (Eds.), Strike-Slip Deformation, Basin Formation, and Sedimentation. Society of Economic Palaeontologists and Mineralogists Special Publications (Vol. 37, pp. 227-264).

Servais, T., \& Sintubin, M. (2009). Avalonia, Armorica, Perunica: Terranes, microcontinents, microplates or palaeobiogeographical provinces? Geological Society, London, Special Publications, 325(1), 103-115. https://doi.org/10.1144/SP325.5

Shaw, J., Johnston, S., \& Gutierrez-Alonso, G. (2015). Orocline formation at the core of Pangea: A structural study of the Cantabrian orocline. NW Iberian Massif. Lithosphere, 7(6), 653-661. https://doi.org/10.1130/L461.1

Shaw, J., Johnston, S. T., Gutiérrez-Alonso, G., \& Weil, A. B. (2012). Oroclines of the Variscan orogen of Iberia: Paleocurrent analysis and paleogeographic implications. Earth and Planetary Science Letters, 329-330, 60-70. https://doi.org/10.1016/j.epsl.2012.02.014

Shelley, D., \& Bossière, G. (2000). A new model for the Hercynian Orogen of Gondwanan France and Iberia. Journal of Structural Geology, 22(6), 757-776. https://doi.org/10.1016/S0191-8141(00)00007-9

Skilling, I. P., White, J. D. L., \& McPhie, J. (2002). Peperite: A review of magma-sediment mingling. Journal of Volcanology and Geothermal Research, 114(1-2), 1-17. https://doi.org/10.1016/S0377-0273(01)00278-5

Solar, G. S., \& Brown, M. (2001). Petrogenesis of migmatites in Maine, USA: Possible source of peraluminous leucogranite in plutons? Journal of Petrology, 42(4), 789-823. https://doi.org/10.1093/petrology/42.4.789

Stampfli, G. M., Hochard, C., Vérard, C., \& Wilhem, C. (2013). The formation of Pangea. Tectonophysics, 593, 1-19. https://doi.org/10.1016/ j.tecto.2013.02.037

Steck, A. (2008). Tectonics of the Simplon massif and Lepontine gneiss dome: Deformation structures due to collision between the underthrusting European plate and the Adriatic indenter. Swiss Journal of Geosciences, 101(2), 515-546. https://doi.org/10.1007/s00015008-1283-z

Strachan, R. A., Linnemann, U., Jeffries, T., Drost, K., \& Ulrich, J. (2014). Armorican provenance for the mélange deposits below the Lizard ophiolite (Cornwall, UK): Evidence for Devonian obduction of Cadomian and lower Palaeozoic crust onto the southern margin of Avalonia. International Journal of Earth Sciences, 103(5), 1359-1383. https://doi.org/10.1007/s00531-013-0961-x

Tait, J. (1999). New Early Devonian paleomagnetic data from NW France: Paleogeography and implications for the Armorican microplate hypothesis. Journal of Geophysical Research, 104(B2), 2831-2839. https://doi.org/10.1029/98JB02787

Tapponnier, P., \& Molnar, P. (1976). Slip-line field theory and large-scale continental tectonics. Nature, 264(5584), 319-324. https://doi.org/ $10.1038 / 264319 \mathrm{a} 0$

Tapponnier, P., Pelzer, B., \& Armijo, R. (1986). On the mechanics of the collision between India and Asia. In M. P. Coward, \& A. C. Ries (Eds.), Collision Tectonics, (pp. 115-157). London: Geological Society Special Publication.

Thompson, A. B. (1999). Some time-space relationships for crustal melting and granitic intrusion at various depths. Geological Society, London, Special Publications, 168(1), 7-25. https://doi.org/10.1144/GSL.SP.1999.168.01.02

Thompson, A. B., Schulmann, K., \& Jezek, J. (1997). Extrusion tectonics and elevation of lower crustal metamorphic rocks in convergent orogens. Geology, 25(6), 491-494. https://doi.org/10.1130/0091-7613(1997)025<0491:ETAEOL>2.3.CO;2

Tikoff, B., \& Teyssier, C. (1994). Strain modeling of displacement-field partitioning in transpressional orogens. Journal of Structural Geology, 16(11), 1575-1588. https://doi.org/10.1016/0191-8141(94)90034-5

Vanderhaeghe, O. (2009). Migmatites, granites and orogeny: Flow modes of partially-molten rocks and magmas associated with melt/solid segregation in orogenic belts. Tectonophysics, 477(3-4), 119-134. https://doi.org/10.1016/j.tecto.2009.06.021

Vanderhaeghe, O. (2012). The thermal-mechanical evolution of crustal orogenic belts at convergent plate boundaries: A reappraisal of the orogenic cycle. Journal of Geodynamics, 56, 124-145.

Vanderhaeghe, O., \& Teyssier, C. (2001). Partial melting and flow of orogens. Tectonophysics, 342(3-4), 451-472. https://doi.org/10.1016/ S0040-1951(01)00175-5

Weil, A. B., Gutiérrez-Alonso, G., Johnston, S. T., \& Pastor-Galán, D. (2013). Kinematic constraints on buckling a lithospheric-scale orocline along the northernmargin of Gondwana: A geologic synthesis. Tectonophysics, 582, 25-49. https://doi.org/10.1016/j.tecto.2012.10.006

Weil, A. B., Van der Voo, R., \& Van der Pluijm, B. A. (2001). Oroclinal bending and evidence against the Pangea megashear: The CantabriaAsturias arc (northern Spain). Geology, 29(11), 991-994. https://doi.org/10.1130/0091-7613(2001)029<0991:OBAEAT>2.0.CO;2

White, J. D. L., McPhie, J., \& Skilling, I. P. (2000). Peperite: A useful genetic term. Bulletin of Volcanology, 62(1), 65-66. https://doi.org/ $10.1007 / \mathrm{s} 004450050293$

Whitney, D. L., Teyssier, C., \& Vanderhaeghe, O. (2004). Gneiss domes and crustal flow. In Gneiss domes in orogeny, Geological society of America, special paper (Vol. 380, p. 15-41). Boulders, Colorado, USA

Yin, A. (2004). Gneiss domes and gneiss dome systems. Geological Society of America Special Papers, 380, 1-14.

Young, T. P. (1990). Ordovician sedimentary facies and faunas of Southwest Europe: Palaeogeographic and tectonic implications. Geological Society, London, Memoirs, 12(1), 421-430. https://doi.org/10.1144/GSL.MEM.1990.012.01.39

Ziegler, P. (1987). Late Cretaceous and Cenozoic intra-plate compressional deformations in the Alpine foreland-A geodynamic model. Tectonophysics, 137(1-4), 389-420. https://doi.org/10.1016/0040-1951(87)90330-1

Ziegler, P. A. (1994). Cenozoic rift system of Western and Central Europe: An overview. Geology in Mijnbouw, 73 , 99-127. 